\title{
Deficiencies of Official Bilingualism in the Finno-Ugric Republics of Post-Soviet Russia: A Legal Perspective
}

As a part of the "parade of sovereignties" during the disintegration of the Soviet Union in the early 1990s, the national republics of Russia designated both Russian and local languages as their state languages. The co-official status of the dominant Russian language by default prevented full-fledged official bilingualism, and serious steps were needed to promote non-dominant local languages in the public sphere. Beyond a mere formal recognition of their official status, the republican authorities passed regulations in order to provide institutional support for the local languages, the amount of which varied across republics. However, the extent of such regulations remains understudied and the best way to evaluate it would be a comparative analysis. What was the level of institutionalization of the official status in the case of titular languages in Russia's republics? This study examines various solutions for framing the official status of titular languages in regional language legislations in order to understand the patterns of institutionalization. The republics titled after the Finno-Ugric peoples were chosen as case studies for the comparison. The study reveals that language legislation contains serious deficiencies in institutionalization of the official status of titular languages, which impede possibilities for their practical use in office.

\section{Introduction}

1. Working languages of authorities

2. The languages in communications of authorities with citizens

3. The languages of public services and other public communications
4. The official languages in the work environment and language preferences
5. The official languages in mass media and education
6. Deficiencies of the laws that undermine official bilingualism Conclusion

\section{Introduction}

The collapse of the USSR marked the beginning of a period of intensive government planning in post-Soviet countries for the change in functioning of languages in society. Acquisition planning, status planning and prestige planning are traditionally distinguished as the three types of language 


\section{Konstantin Zamyatin}

planning that correspond, accordingly, to the actions directed at creating capacity, opportunity and desire to use languages (see Cooper 1990: 100103). It was status planning that became the cornerstone of the language policies not only in the newly independent states but also in the national republics of Russia (see Zamyatin 2013a: 125-126). Status planning means that a certain language or languages are designated with an official status in order to ensure exclusive use of said language(s) in the public sphere.

In their declarations of state sovereignty in 1990, Russia's national republics proclaimed state languages as one more symbol of their national statehood: almost without exceptions, the status of state language was given to both the titular and Russian languages (see Zamyatin 2013a: 134-136). Russia's language law (25 October 1991) and the Russian constitution (12 December 1993) established Russian as the state language of the whole country and retroactively recognized the right of the republics to establish their state languages (article 68). By the mid-1990s, most republics had established state languages in their constitutions. The constitutional designation amounted to symbolic recognition and had not resolved the problem of the lack of practical use of the titular languages, which had to be dealt with in language laws (see Zamyatin 2013b, 2013c).

This situation of the use of two or more languages in the public sphere of the republics was sometimes described as official or legal bilingualism. In the strict sense, in the case of the republics, one can only speak of the official status of the languages, because official bilingualism was not considered a policy goal or a result, but rather a policy tool. The relation between Russian and the titular languages in their official status was not clarified. The legislation does not use the term "co-official languages", and their co-existence in the public sphere is rather a sociolinguistic and political fact than a solution for the potential problems stemming from their competition. Will Kymlicka (2001: 78-79) witnesses that for the survival of a minority language, an exclusive official status might be necessary in the region where its speakers are predominant (see also Ruíz Vieytez 2004). However, language survival is not the only reason for the official designation of a minority language (see Zamyatin 2014a: 97-103). Furthermore, what happens if both majority and minority languages are designated as official, while the minority language is not predominant in that territory?

Russian remains the language that regional authorities predominantly and often exclusively use, whereas the titular languages were introduced in only a few elements of the public domains. This situation is sometimes 
characterized as that of "limited officiality" (see Ruíz Vieytez 2004). The federal design limited the extent to which titular languages could be institutionalized. Among branches of power, the judicial sector is in federal competence and so are the regional representations of federal authorities among the executive authorities. For example, law enforcement agencies are typically monolingual: a policeman will speak in the dominant language. Among regional executive authorities, the financial block will be typically monolingual and only in some republics, e. g. Tatarstan (RT), a local language might also be used to some extent. An important issue is language requirements for the republic's chief executive official, which is discussed at length elsewhere (see Zamyatin 2013b). Regional legislatures, some regional executive authorities (notably those in human resources) and municipalities can be bilingual. Most instances of bilingualism can be found in public institutions, such as public schools, mass media and cultural centres (see Zamyatin 2015: 123-125).

Furthermore, despite equation of Russian and the titular languages in their status of the state languages of the republic, the higher status of Russian as the state language of the whole country works as the mechanism that has allowed policy-makers and implementers to restrict the use of titular languages to a symbolic function and to impede the expansion of their practical use (Zamyatin 2015: 126-127). The ethnic elites identified the gap between the symbolic and practical use of titular languages as the problem and the "revival" of titular languages as its solution. Responding to their claims, the republican authorities recognized the expansion of the use of titular languages in the public sphere through the adoption of language laws as the goal of language policy. Within the scope available for the expansion, i. e., limited by the federal design, the amount of elements institutionalized in language legislation varied across the republics and depended, first of all, on the strength of national movements and the ability of ethnic elites to bargain among the ruling elites (see Zamyatin 2013c: 140-143, Zamyatin 2014a: 103-104).

Difficulties in reaching a compromise resulted in the vague character of the republican language legislations and insufficient support for the promotion of titular languages. The problem of all republican language laws, written in the Soviet legislative tradition, is that they basically remained declarative documents. The republican language laws, instead of formulating clear mandatory rules and institutionalizing elements of domains for the usage of the state languages in the republics, merely replicated the permis- 
sive style of the provisions of Russia's language law. The language laws put forward norms that are not directly applicable and do not reflect the actual steps taken by authorities for language promotion. The crucial point is that the laws are typically not directly enforceable on the republican authorities, and in many respects merely allow the use of the state languages. Their permissive legal norms created the gap that many republican authorities use for inaction and to escape from engaging practices of language use for titular languages in many elements of the domains of the public sphere. The greater part of norms concerning the functioning of the titular languages as the state languages is there only on paper (see Zamyatin 2013c: 143).

From the perspective of sociolinguistic theory, the larger the number of domains where a minority language is used, the safer its sociolinguistic situation will be. The opposite correlation might be also true: the stronger ethno-linguistic vitality of a group and the better maintained a language, the better the language will be also institutionalized in the public sphere. The purpose of this study is to explore what elements of the official status were institutionalized in relation to titular languages, in order to look for the patterns of institutionalization. Institutionalization of languages can be defined here as the enactment of language use in certain institutional contexts. The approach of the study is a comparative analysis along both qualitative and quantitative criteria. There are some comparative studies that have investigated the languages laws from a legal perspective in the Volga Turkic Republics, the Republics of Siberia and the North Caucasus (see e. g. Gorenburg 2003, Katunin 2009 and Gučigov 2013), but, with some partial exceptions (see Janush 2013), there has been no such study for the FinnoUgric Republics. The case studies in the Republics of Komi (KR), Mari El (RME), Udmurtia (UR), Mordovia (RM) and Karelia (RK) provide the analysis with a variety of configurations, ranging from the absence of the status of state language for the titular language (Karelia) up to an "equated" official status (Komi). At the same time, the context of the officialization is similar, as in all these republics the titular group is in the minority (see Zamyatin 2014a: 29-30). One of the tasks of the article is to provide the catalogue of such elements in the public domains of language use in each of the republics under consideration (for an analogous catalogue in the case of late-Soviet Tatarstan see Isxakova 2002: 9-10).

The study is not restricted to the analysis of institutionalization of titular languages in language laws, but follows the change through the analysis of amendments to laws. While the expansion of titular languages in the 
republics through the adoption of regional language laws was a policy priority in the 199os, it began to face obstacles after the overall policy shift in Russia towards recentralization and re-establishment of the "power vertical" in the late 1990s and early 2000 (see Zamyatin 2015: 138-140). Marking a shift in language policy, Russia's language law was amended twice and resulted in deterioration of the position of non-Russian languages, e. g. by making the use of Cyrillic script compulsory for the state languages (Federal Laws, 24 July 1998 and 11 December 2002; see Zamyatin 2015: 136-137). However, even the 1998 revision had not solved the problem of the declaratory character of its legal provisions. Instead, the list of public domains and public services where the use of Russian is compulsory was enacted in a separate law (Federal Law, 1 June 2005) that reinforced the dominant position of the Russian language. There are no such new laws and respective lists in republican language legislations, except in Tatarstan (RT Law, 12 January 2013). The revivalist agenda in the republics has fallen by the wayside since the late 2ooos. Accordingly, there have been two waves of amendments to the regional language laws: one in the early 2000 and the other in the late 2000 (the amendments are studied in more detail in Zamyatin 2013c: 144-146).

The structure of the study is organized along the domains of language use in the public sphere. Joshua Fishman famously developed the Gradual Intergenerational Disruption Scale (GIDS) (Fishman 1991: 87-109). According to his scale, the part that is aimed at transcending diglossia and normalizing language use in the public sphere consists of four stages (Fishman 1991: 400). The four domains that constitute the public sphere of language use are: 1) languages in office of authorities and organization, 2) language in the work environment, 3) languages in mass media, and 4) languages in education (for a more detailed description, see Zamyatin 2014a: 47-53). For the purpose of the comparison, the elements of the first domain in Fishman's taxonomy were further divided, depending on whether the languages are used by public authorities internally in office or externally in communications with citizens. Furthermore, public services as communications taking place on a regular basis were separated into a third group. This distinction is conditional, inter alia, because languages in the work environment, mass media and education are also public services. However, these are the most important domains in functioning of non-dominant languages, which justifies their detachment into separate categories. 
The structure of the study follows the sequence of the domains and their elements according to how they appear in the language legislation: (1) the working languages of authorities, (2) the languages in communications of authorities with citizens, (3) the languages of public services and other public communications, and the particular public services of (4) the official languages in the work environment and language preferences, (5) the official languages in mass media, and (6) the official languages in education. The analysis demonstrates that among the elements of the state languages of republics, those conveying a symbolic message were more institutionalized in the case of titular languages than those demanding their communicative use.

\section{I.Working languages of authorities}

This domain represents the functioning of the official languages as the working languages of the republican authorities, but also of the municipal authorities. Official language use in this domain includes the following main elements: (a) the working languages in the activities of the republican and municipal authorities and legal entities, (b) the languages of drafts and legislative procedure, (c) language-use management of public businesses, (d) language use in official correspondence.

(a) Russia's language law states that the work of the federal and regional authorities as well as the bodies of the local self-government is carried out in the state language of the Russian Federation (RSFSR Law, 25 October 1991, article 11). The law also allows the use of state languages of the republics and other languages of the peoples of the Russian Federation in activities of regional authorities and organizations (article 15). In the relations between the federal and regional authorities, Russian is used (article 27). The bilateral treaties between the federal and regional authorities on the distribution of powers are made in Russian (Federal Law, 6 October 1999, article 27).

According to the original version of the language law of the Komi Republic, sessions of state authorities and legal entities had to be held in Komi and Russian (Law KR, 28 May 1992, article 7). Unlike in the other republics, the titular Komi language was and is not only on paper but indeed the working language at least among the authorities of remote municipalities. According to the 2002 amendment, the sessions are held in Russian, and the Komi language only can be used (Law KR, 16 July 2002). This amend- 
ment came unexpectedly for the national organization. Now, according to the law, Russian has to be used (Cypanov 2003: 37-38). However, the sessions of the State Council continue to be held in Komi and Russian and are provided with synchronized translation (Rules of the Procedure, 7 February 1995, article 40 (new Rules of the Procedure, 18 December 2002).

In Mari El, the republican state languages "are" the official and working languages of the state authorities (Law RME, 26 October 1995, article 15), as well as of state and other public organizations (article 22). But these provisions remain declarative, too. The language law of Mari El in the original text formulated analogical provisions not as the deputy's right, but as the obligation of official and civil servants to be proficient in one of the republican state languages in the amount needed for work (article 14). With the 2001 amendment, the scope of the obligation was narrowed: the officials are obliged to know the state language of the Russian Federation and "one of the republican state languages", that is, the Russian or Mari languages (Law RME, 19 September 2001). Thus, there is no longer any obligation to know the titular languages. There is the right to use the other languages at the sessions and in the committees and presidium sessions of the State Assembly, too. This right is ensured by providing translations (article 16). There is no according provision of the deputies' right of language use in the Rules of the Procedure of the State Assembly; it only copies the provision of the republican Constitution on taking an oath by republican President in the Mari and (or) Russian languages (Rules of the Procedure, 24 September 2009, article 131). However, the officials never use the titular languages in Mari El, although the usage of the republican state languages by authorities and legal entities is stipulated by the law (article 15, 22).

According to the law in Udmurtia "the working language of the state authorities is Russian; Udmurt can be used side by side with Russian" (Law UR, 27 November 2001, article 9). The state languages of the republic "are used" in activities of the republican authorities and legal entities in Udmurtia, according to the order defined by the federal and republican legislation (article 16). However, this order of was never defined, and the Udmurt language is hardly ever used in the work of authorities. In Udmurtia, the deputies and officials have the right to use at their will one of the republican state languages or other languages at the State Council and Government sessions, as well as their presidiums' and commissions' sessions (article 9). This is the only provision that is further elaborated. It is stated in the Rules of the Procedure of the State Council that, in order to use this right, the deputy must 


\section{Konstantin Zamyatin}

inform the secretariat of his intention to make his speech in the Udmurt language. The secretariat is responsible for providing translations (Rules of the Procedure, 26 April 1995, article 22 (new Rules of the Procedure, 17 April 2001, article 9; new Rules of the Procedure, 25 November 2008, article 36). The secretariat is called the apparatus in the later Rules of the Procedure). In practice, the deputies never use this right. Furthermore, the Rules of the Procedure do not include a provision on the obligation of the President to take an oath in the state languages, as do the Rules of the Procedure of the Mari parliament. In practice, however, the President did "take" an oath in both state languages, the last time in January 2010, but despite the sequence of languages in the constitution, did it first in Russian and then in Mari. The court acknowledged the lawfulness of this action (RME Yoshkar-Ola Town Court Judgment, 16 March 2011).

According to the language law of Mordovia, the state languages of the republic "are used" in the activities of the republican authorities and legal entities (Law RM, 26 May 1998, article 16). In Mordovia the deputies wishing to speak in the Mordvin (Moksha or Erzya) language at a session of the State Assembly, its Council, committees or commissions must inform the secretary of the Council in advance. The secretariat is responsible for providing translations (article 12). The same provision is restated in the Rules of the Procedure of the State Assembly of the Republic of Mordovia. It is proclaimed that the work of the State Assembly is carried out in the Russian and Mordvin (Moksha or Erzya) languages (Law RM, 10 March 1995, article 16 (new Law, 14 February 2002). There is no provision on the obligation of the President to take an oath in the state languages.

In Karelia, state and municipal authorities as well as legal entities can use the Karelian, Veps and (or) Finnish languages in their work, along with Russian (Law RK, 19 March 2004, article 8). However, there is no elaboration of this provision. The Legislative Assembly of the republic works in Russian and speeches in other languages are translated to Russian (RK Legislative Assembly Decree, 17 May 1994, article 15).

The laws of Komi and Mordovia regulate only official language use by state authorities, not by municipal authorities. Furthermore, there was no separate provision on language use by municipal authorities in the Komi language law, because at the time it was adopted there was no local self-government, but instead local state authorities. The 2002 amendment included the provision that the sessions of municipal authorities are held in Russian, and the Komi language can be used (article 7). The activities of municipal 
authorities and legal entities in Udmurtia "are performed" in the republican state languages or other languages, according to the order defined by the federal and republican legislation (article 17). This order of functioning was not further defined either. In Mari El, municipal authorities previously had to use "equally one of the republican state languages" or other local languages (article 18). With the 2001 amendment, this provision was reformulated in such way that "municipal authorities use the state language of the Russian Federation for document circulation, whereas the republican state languages can also be used".

(b) Legislative procedure includes the language(s) of drafts, the language(s) of draft discussions in parliament and its committees, which assumes also the right of deputies to speak in the language of their choice, and the language(s) of publication of laws. Russia's language law in its original text stated that it is an obligation of the republican state authorities to provide the official publication of the federal laws in the state languages of the republics, but since the 1998 amendment this is only formulated as a possibility (Federal Law, 24 July 1998, article 12; see Gubaeva \& Malkov 1999: 6). The Russian language must always be used by the official publication as it is the state language of the Russian Federation, whereas the official publication of all documents in the titular languages in the republics is not compulsory, and in practice, only the most important laws, constitutions and laws on languages are translated (Vasil'eva 2008: 31). The main obstacle for translation is a lack of qualified translators (Semënov 2008: 23). In addition, there is the problem of authenticity of translation (Vasil'eva 2007: 24-26).

In Komi, drafts of laws and other acts of the authorities previously had to be discussed and published in Komi and Russian, and both would have equal juridical force (article 7). The 2002 amendment excluded the demand for these documents to be discussed also in Komi. According to the Law, which defined the order of publication and enforcement of laws and other legal acts, laws, legal acts of the Head of the Republic, State Council, Constitutional Court, Government, Ministries and other executive authorities, as well as the Treaties of the Republic, are published in the state languages in the official periodical "Gazette of the Normative Acts of the Authorities of the Komi Republic" (Para 2, 4, 6, 8, KR Government Decree, 5 February 2008). The monthly issues of this periodical must be identical in both languages. Additionally, the issue in the Komi language contains information on the authority that translated the document. The translations are made 


\section{Konstantin Zamyatin}

by the Ministry for Nationalities Policy (Law KR, 16 October 2002, article 11). In Komi, unlike in the other republics, translations of all legal acts are indeed arranged.

In Mari El, law drafts could initially be presented in one of the republican state languages (article 17). With the 2001 amendment, law drafts must be presented in the state language of the Russian Federation, whereas the republican state language can be used. It is implied that the laws are discussed in the republican state languages, because "activities of the supreme authorities are performed in the state languages of the Republic of Mari El", but this never happens. Texts of laws are published in the state languages (RME Law, 26 January 1996, article 4). Texts of published documents are official in the state languages of the republic (article 17). In Udmurtia, law drafts and drafts of other acts of the authorities are presented and discussed, and laws are officially published in Russian; laws and other official documents can be officially published also in Udmurt (article 10). The respective state or municipal authority takes the decision on official publication in Udmurt (Law UR, 21 June 2010, article 10). For many years there was a plan to adopt a government decree, which was supposed to approve the order of official publication of laws and other legal acts of the authorities of the Udmurt Republic, as well as and acts of local self-government, in both state languages of the Udmurt Republic. In Mordovia, laws and other legal acts had to be drafted and discussed in Russian. Legal acts of municipal authorities could be issued in the Mordvin (Moksha or Erzya) languages (Law RM, 21 February 2002, article 17; Law RM, 1 June 2000, article 9). Texts of laws and other legal acts had to be officially published in the state languages and would have equal juridical force (article 13). With the 2010 amendment, this provision was excluded (Law RM, 12 March 2010). In Karelia, state and municipal authorities can publish laws and legal acts containing provision on human rights and citizens' obligations in the Karelian, Veps and Finnish languages in mass media. The decision on publication is taken by the authority in question (article 6) (Law KASSR, 6 May 1990; Law RK, 24 May 2000).

(c) According to Russia's language law, the official business documentation of government bodies, organizations, enterprises and institutions is produced in Russian, while in the republics, their state languages can be used (article 16). In Komi, management of public affairs and circulation of official documents among the republican authorities previously had to be 
carried out in Komi and Russian (article 7). After the 2002 amendment, it is carried out in Russian, while the Komi language can be used. Similarly, the official document circulation and texts of documents in Mari El "are conducted" in the republican state languages (article 25), or also in local languages according to the order defined in the republican legislation (article 27). However, the document circulation order does not regulate the official language used. The language use in the management of public businesses, in official document circulation and public notices "is performed" by the republican authorities, municipalities and legal entities in Udmurtia in the republican state languages according to the order defined in the legislation (article 18). The order, however, was not defined. This demand was one of those strongly opposed at the time of adoption of the language laws (Bannikova 2001). There has never been any tradition of using Udmurt in this field. Management of public affairs and official document circulation in Mordovia is performed in Russian and, "if necessary", can also be performed in Mordvin (Moksha or Erzya) (article 11). In Karelia, municipal authorities and legal entities can use the Karelian, Veps and (or) Finnish languages, along with Russian, in official document circulation where speakers of these languages live compactly (article 8).

(d) According to Russia's language law, Russian, as the state language of the whole country, is the sole language of official correspondence and other forms of official relations between the authorities and organizations on the level of the federation, while inside the regions other languages can be used (article 17). Any of the state languages can be used in official correspondence between authorities and legal entities within the Komi Republic (articles 8). Within Mari El, it is implied that official correspondence is performed in the republican state languages (article 49). The republican authorities "use" any of the republican state languages outside the republic depending on the recipient (article 19). In 2001, article 19 was excluded. Russian is being used in official correspondence outside the republic (article 29). The language of official correspondence between authorities and legal entities within Udmurtia is Russian, but can also be Udmurt; the language of official correspondence with authorities and organizations outside Udmurtia is Russian only (article 19). There is no respective separate provision on official correspondence either in the language law of Mordovia or in the law of Karelia.

The joint data on language use in office are presented in Table 1. Altogether, in the republics, neither the laws on the Parliament or on the 


\begin{tabular}{|c|c|c|}
\hline Republic & Komi & Mari El \\
\hline Language law & 1992, amended 2002, 2009 & $\begin{array}{l}\text { 1995, amended 2001, } \\
\text { 2008, 2009, } 2011\end{array}$ \\
\hline $\begin{array}{l}\text { (a) Working } \\
\text { languages of } \\
\text { authorities and } \\
\text { legal entities }\end{array}$ & $\begin{array}{l}\text { 1992: Komi and Russian; } \\
\text { 2002: Russian, Komi } \\
\text { can be used. }\end{array}$ & State languages. \\
\hline $\begin{array}{l}\text { Rights and } \\
\text { obligations } \\
\text { of officials }\end{array}$ & $\begin{array}{l}\text { Deputies have the right to } \\
\text { speak in Komi or Russian. }\end{array}$ & $\begin{array}{l}\text { 1995: obligation of official } \\
\text { and civil servants to know } \\
\text { one of the republican state } \\
\text { languages in the amount } \\
\text { required for work } \\
\text { 2oo1: officials are obliged } \\
\text { to know the state language } \\
\text { of the Russian Federation } \\
\text { and "one of the republican } \\
\text { state languages". }\end{array}$ \\
\hline $\begin{array}{l}\text { Working } \\
\text { languages in } \\
\text { activities of } \\
\text { municipal } \\
\text { authorities }\end{array}$ & $\begin{array}{l}\text { 2002: Russian, Komi } \\
\text { can be used. }\end{array}$ & $\begin{array}{l}\text { 1995: "equally one of the } \\
\text { republican state languages" } \\
\text { or other local languages. } \\
2001: \text { "the state language } \\
\text { of the Russian Federation } \\
\text { for document circulation, } \\
\text { whereas the republican state } \\
\text { languages can also be used". }\end{array}$ \\
\hline $\begin{array}{l}\text { (b) Language } \\
\text { use in the } \\
\text { legislative } \\
\text { procedure }\end{array}$ & $\begin{array}{l}\text { 1992: drafts of laws and } \\
\text { other acts of authorities } \\
\text { discussed, published in } \\
\text { Komi and Russian and have } \\
\text { equal juridical force. } \\
\text { 2002: drafts of laws and other } \\
\text { acts of authorities discussed } \\
\text { in Russian, published in } \\
\text { Komi and Russian and have } \\
\text { equal juridical force. }\end{array}$ & $\begin{array}{l}\text { 1995: law drafts could be } \\
\text { presented in one of the } \\
\text { republican state languages, } \\
\text { discussed in the republican } \\
\text { state languages. } \\
\text { 20o1: law drafts have to be } \\
\text { presented in the state language } \\
\text { of the Russian Federation, } \\
\text { whereas the republican state } \\
\text { language can be used. }\end{array}$ \\
\hline $\begin{array}{l}\text { (c) Language } \\
\text { use in official } \\
\text { document } \\
\text { circulation and } \\
\text { public notices }\end{array}$ & $\begin{array}{l}\text { 1992: Komi and Russian; } \\
\text { 2002: Russian, Komi } \\
\text { can be used. }\end{array}$ & $\begin{array}{l}\text { The republican state } \\
\text { languages, or also in } \\
\text { local languages. The } \\
\text { order is not defined. }\end{array}$ \\
\hline $\begin{array}{l}\text { (d) Language } \\
\text { use in official } \\
\text { correspondence }\end{array}$ & $\begin{array}{l}\text { Any of the state languages } \\
\text { within the republic. }\end{array}$ & $\begin{array}{l}\text { The republican state languages } \\
\text { within the republic. }\end{array}$ \\
\hline
\end{tabular}

Table 1: Working languages of authorities 


\begin{tabular}{|c|c|c|}
\hline Mordovia & Udmurtia & Karelia \\
\hline 1998, amended 2010 & 2001, amended 2010 & 2004 \\
\hline $\begin{array}{l}\text { Russian; Mordvin } \\
\text { (Moksha and Er- } \\
\text { zya) can be used. }\end{array}$ & $\begin{array}{l}\text { Russian; Udmurt } \\
\text { can be used. }\end{array}$ & $\begin{array}{l}\text { Russian; the Karelian, } \\
\text { Veps and (or) Finnish } \\
\text { languages can be used. }\end{array}$ \\
\hline $\begin{array}{l}\text { Deputies have the right } \\
\text { to speak in the Mordvin } \\
\text { (Moksha and Erzya) } \\
\text { language at sessions; the } \\
\text { deputy has to inform } \\
\text { about his intention, } \\
\text { translation provided. }\end{array}$ & $\begin{array}{l}\text { Deputies and officials } \\
\text { have the right to use } \\
\text { at their will one of } \\
\text { the republican state } \\
\text { languages or other } \\
\text { languages at sessions; } \\
\text { the deputy has to inform } \\
\text { about his intention, } \\
\text { translation provided. }\end{array}$ & No separate provision. \\
\hline No separate provision. & $\begin{array}{l}\text { Activities of municipal au- } \\
\text { thorities "are performed" } \\
\text { in the republican state lan- } \\
\text { guages or other languages, } \\
\text { according to the order } \\
\text { defined by the federal and } \\
\text { republican legislation. } \\
\text { This order is not defined. }\end{array}$ & $\begin{array}{l}\text { Russian; the Karelian, } \\
\text { Veps and (or) Finnish } \\
\text { languages can be used. }\end{array}$ \\
\hline $\begin{array}{l}\text { 1998: Laws and other } \\
\text { legal acts are prepared } \\
\text { and discussed in Russian, } \\
\text { officially published in the } \\
\text { state languages and have } \\
\text { equal juridical force. } \\
\text { 2010: provision excluded. }\end{array}$ & $\begin{array}{l}\text { Law drafts are presented } \\
\text { and discussed, and laws } \\
\text { are officially published } \\
\text { in Russian; laws can } \\
\text { be officially published } \\
\text { also in Udmurt. }\end{array}$ & $\begin{array}{l}\text { Russian; the Karelian, } \\
\text { Veps and (or) Finnish } \\
\text { languages can be used in } \\
\text { publication of laws and } \\
\text { legal acts containing pro- } \\
\text { visions on human rights } \\
\text { and citizens' obligations. }\end{array}$ \\
\hline $\begin{array}{l}\text { Russian; Mordvin } \\
\text { (Moksha and Erzya) } \\
\text { if necessary. }\end{array}$ & $\begin{array}{l}\text { The republican state } \\
\text { languages. The order } \\
\text { is not defined. }\end{array}$ & $\begin{array}{l}\text { Russian; the Karelian, } \\
\text { Veps and (or) Finnish } \\
\text { languages can be used, } \\
\text { where speakers of these } \\
\text { languages live compactly. }\end{array}$ \\
\hline No separate provision. & $\begin{array}{l}\text { Russian within the } \\
\text { republic, but can } \\
\text { be Udmurt, too. }\end{array}$ & No separate provision. \\
\hline
\end{tabular}




\section{Konstantin Zamyatin}

Government, nor the other respective laws on public activities have any further language provisions that would have clarified official language use (Law KR, 24 October 1994 (19 December 2006); KR Government Decree, 23 May 2002; Law RME, 7 December 2001; Law RME, 28 June 2005; Law RME, 15 February 1994; Law RME, 18 September 2001; RME Government Decree, 10 April 2001 (2 October 2006); Law UR, 14 December 1994 (6 March 2001 and 5 December 2007); Law UR, 30 May 1995; Law UR, 26 February 2008; Law UR, 16 May 1995 (2 March 2001); UR Government Decree, 24 January 2003; Law RM, 19 March 2004; Law RM, 10 March 1995; Law RM, 28 February 1997; Law RM, 16 April 1996 (12 November 2001); RM Government Decree, 10 June 1998. Law RK, 19 April 1991; RK Legislative Assembly Decree, 17 May 1994; Law RK, 17 January 1994; RK Legislative Assembly Decree, 22 February 2007; Law RK, 14 September 1994; RK Legislative Assembly Decree, 24 May 2007; Law RK, 27 April 1999).

An exception to this is the addition in the new laws of the principle of prohibition of discrimination based on language. Despite the existence of general entitling provisions, a legal mechanism for their execution has not been created. It is no surprise, then, that the titular languages are practically never used within the walls of the buildings of the authorities. The only exception is that sometimes the titular languages are used in the legal translations by official publication of the most important laws, such as the republican constitution and the language law. Additionally, some official news articles and press releases of the authorities are published in the titular languages.

In part, the poor official bilingualism in the office of the state authorities can be explained, inter alia, by insufficient development of public vocabulary in non-dominant languages. This problem is being addressed by activities of the republican termini-orthography commissions (language boards) and activities of research institutes in education and other scientific institutions (the time of creation of the language boards differed: KR Council of Ministers Decree, 25 April 1994; UR Government Decree, 13 November 1995, 5 December 2005; UR President Decree, 8 December 2005; RK Government Chairman Decree, 25 May 1998; RK Head Decree, 29 May 2003; RME Government Decree, 8 July 2000, 29 March 2001; RM Government Decree, 25 October 2010). However, there is a further problem of standardization when the population refuses to accept the new vocabulary. Even those rare politicians who are otherwise fluent in the titu- 
lar language are reluctant to use it in formal contexts. For example, they would refuse to give speeches or interviews in it and switch to Russian, because of the lack of suitable vocabulary (see Zamyatin 2014a: 116-117). A systemic reason for the poor language knowledge would be the unavailability of higher professional education in the titular languages. Due to political under-representation of minorities, as discussed above, bilingual politicians are rare. Nowadays it is still easier to spread new political and legal vocabulary within the state authorities in written form. A lack of vocabulary leads to low language prestige and provokes another, deeper reason for the absence of bilingualism, which is the attitudes of Russianspeaking legislators towards the titular languages as stigmatized minority languages.

\section{The languages in communications of authorities with citizens}

Communications of authorities with citizens are another aspect of the functioning of the republican state languages in the public sphere. Communications include language use in: (a) legal proceedings, (b) elections and referenda, (c) requests of citizens, and (d) documents issued by authorities.

(a) The courts and the whole judicial system are, on the one hand, a part of the state apparatus, but on the other hand, they form a sphere of communications of authorities with citizens. Courts and law enforcement agencies in Russian are in federal competence and, thus, unilingual, although the original text of the language law allowed also the use of the state languages of republics in proceedings and documentation in the courts and paperwork in the law enforcement bodies (article 18). The rules of judicial proceedings apply also to the notarial paperwork (article 19; also Fundamentals of the Legislation on Notariate, 11 February 1993, article 10).

Court proceedings in the Komi Republic and state notarial management had to be performed in Komi and Russian (articles 9, 10). This provision was used in practice in 1995 during a trial, in which one of the parties spoke Komi. The judge interpreted this provision narrowly. The Komi language was not used as the language of the court process, but translation was allowed, although the party itself had to pay for the interpreter. The man accepted the interpreter, but refused to pay. The court paid the costs 


\section{Konstantin Zamyatin}

(Taagepera 1999: 332). In 2002, these provisions were amended in such a way that the issues of court proceedings and notarial management would be regulated by federal legislation.

In Mari El, administration of justice and legal proceedings by courts and law enforcement authorities had to be carried out in the state languages or other languages (article 30). The 2001 amendment reformulated this provision in such a way that the administration of justice and court proceedings in the Constitutional Court and other courts in the republic would be carried out in the Mari and Russian languages. Every participant in the legal process has the right to speak in the court in one's own language. Those not having command of the language of the legal proceedings enjoy the possibility of using the services of an interpreter (article 31). The acts of the Public Prosecutor's Office previously had to be in the Mari and Russian languages (article 33), but this provision was excluded with the 2001 amendment. The order of language use in the administration of justice and by law enforcement is defined by federal legislation (article 32). The language law of Udmurtia contains no provisions in this sphere except for notarial management, where the documents can be issued in either of the state languages, depending on the wish of a citizen (article 20). In Mordovia, legal proceedings and notarial management are conducted in Russian and, if needed, in Mordvin (Moksha or Erzya) (article 11). With the 2010 amendment, this provision was excluded.

(b) Elections and referenda are one of the core elements of a democratic society. They are arranged by authorities for ensuring political participation of citizens in societal life. Authorities pay attention to ensure minority political participation. The importance of this element of the political system forces also the legislation to provide clear rules on the use of minority languages. Russia's language law states that, along with Russian, the republics have the right to use the state languages of the republics and other local languages in preparing and holding elections and referenda; the same rule applies also to ballot papers (article 14).

In the original version of the Komi language law, Komi and Russian had to be used in the arrangement and holding of elections and referenda at all levels (KR Election Law, 15 June 1995, article 12). The 2002 amendment added the possibility to print bulletins in Komi and Russian by decision of election or referendum committee according to federal and repub- 
lican legislation (KR Election Code, 16 June 1998, article 62; Law KR, 7 July 2006, article 22).

In the original version of the Mari El language law, the Mari (Hill, Meadow) and Russian languages, but also other local languages, "are used" in the arrangement and holding of the republican and municipal elections as well as referenda (article 20). The latter additionally contains the provision of the previous article 21, excluded by the 2009 amendment (RME Law, 16 March 2009), on the bulletins, which are published in Russian with a translation into the Mari languages and, if necessary, into other local languages by decision of the election or referendum commission (according provisions in the RME Election Law, 10 November 1993, article 71 (new Law, 11 June 2003); RME Referendum Law, 11 June 2003, articles 7, 52).

In Udmurtia, the republican state languages "are used" in the arrangement and holding of federal, republican and municipal elections and referenda, whereas other local languages can be used. However, the bulletins are published in Russian, although they can be published in Russian and Udmurt and, if necessary, in other local languages by decision of the election or referendum commission (article 15). A similar provision is given in article 52 of the new law on referendum (Law UR, 29 March 2007). According to the original law, the bulletins had to be published in the languages of the majority of the election district (Law UR, 23 January 1994, article 32 (new Laws, 1 June 2003 and 13 April 2007, article 52)). It is interesting that, in addition to the according provision of the Language Law, the texts of draft laws and decisions have to be in the republican state languages according to the referendum law (Law UR, 18 December 2002, article 4). Article 44 on the bulletins replicates the provision of the Language Law (new Law, 29 March 2007, article 43).

In Mordovia, the Russian and Mordvin (Moksha or Erzya) languages "are used" in the arrangement and holding of republican elections and referenda (article 14, 15). The bulletins are published in Russian, but some bulletins can be published by decision of the election or referendum commission in both the Russian and Mordvin (Moksha or Erzya) languages (Law RM, 17 February 1994, article 69 (new Law, 27 June 2003); Law RM, 27 July 1995, article 48 (new Law, 23 January 2004).

In Karelia, the Karelian, Veps and (or) Finnish languages can be used along with Russian in the territories where speakers of these languages live in the arrangement and holding of republican elections and referenda on 


\section{Konstantin Zamyatin}

issues involving human rights and citizens' obligations as well as in bulletins by decision of the election or referendum commission (article 7) (Law RK, 17 January 1994; Law KASSR, 24 April 1991; Law RK, 10 November 1993 (28 November 1997).

(c) Transparency of public authorities and their accountability to citizens is another important element of a democratic society, which also has a language component. According to Russia's language law (article 15), citizens have the right to address authorities in the language of their choice and to receive a response from the authorities in the same language "except in cases when it is impossible". The law does not specify the conditions of impossibility (see Ulasiuk 2011: 79).

In Komi, citizens have the right to make requests to authorities and legal entities in the Komi and (or) Russian languages (article 4). Authorities address citizens in Komi or Russian, depending on citizen's wish (article 14). The 2002 amendment gave the right to make requests to authorities also in other languages of the peoples of Russia. The answers are given in the language of request or in the state languages. A law on requests of citizens was adopted, however it was annulled in the same year.

According to the language law of Mari El, in the public spheres, a citizen has the right to choose for oral information to be provided and documents to be issued in one of the state languages of the Republic of Mari $\mathrm{El}$, or in other local languages (article 8). In order to execute this right, the original version of the law stated that: "state and municipal authorities, organizations, and their officials, respond to written requests of citizens in the language in which the request was made" (article 9). With the 2001 amendment, the obligation of authorities to respond in the language requested was replaced with the obligation to respond in the republican state languages or in Russian. With the 2008 amendment, the responses are given in the language of request, "unless it is impossible" (RME Law, 2 December 2008).

According to the language law of Udmurtia, citizens have the right to make requests to the republican and municipal authorities and legal entities in the republican state languages (article 16). Responses are given in the language of request or, "in case of impossibility", in Russian.

According to the language law of Mordovia, Russian or Mordvin (Moksha or Erzya) previously had to be used in the relations of authorities and legal entities with citizens (article 7). However, the 2010 amendment 
states that citizens are free to choose the language of communication with authorities and municipalities.

The formula "the responses are given in the language of the request, unless it is impossible" is incorporated in the republican language laws of the provisions of the federal laws on information (Federal Law, 27 July 2006, 9 February 2009). The Federal Law on Information recognized the right of citizens to have access to information, including the right to receive information from state authorities and public organizations. In order to ensure this right, the authorities and organizations have the obligation to provide access to information about their activities in Russian and in the republican state language according to the legislation (article 8). According to the federal law, the state authorities and municipalities create information systems and provide access to their information in Russian and the republican state languages (article 12). The information systems are databases as well as information technologies and technical means used in their creation.

Some spheres of official language use were relatively new at the time of adoption of language laws and developed later. First of all, this concerns the sphere of new information technologies, which is regulated now by the above-cited Federal Law on Information. In the republican language laws, language use in internet technologies is still not regulated. The language law in Mari El has a rather undefined provision that "in the Republic of Mari El informatics is performed on the basis of the republican state languages" (article 40). Consequently, until the late 2000 s the official republican servers and web-pages in Komi, Mari El, Udmurtia, Mordovia and Karelia were almost exclusively in Russian, which was breach of the right of access to information. At the same time, for instance, the official server of the Republic of Tatarstan was already fully in Russian, Tatar and English in the early 20oos. Only after the adoption of the federal law on information did the web pages start to be translated with modest progress.

(d) Russia's law states that the texts of the documents and signboards with the names of government bodies and organizations are drawn up in the state language of the Russian Federation, the state languages of the republics and other local languages (article 15).

Names of legal entities, texts of official seals, stamps, document forms and advertisements are written in Komi and Russian (article 25). Official 


\section{Konstantin Zamyatin}

documents testifying the identity of a citizen and other information, including passports, work identification cards, education certificates and diplomas, birth, marriage, death certificates and other documents are issued in Komi and Russian (article 11). The 2002 amendment added the condition that the documents must be issued according to federal legislation. The order of the Ministry for Nationalities Affairs approved the rules for making the design of signboards of legal entities, letterheads, texts of seals, stamps and document forms in the state languages (Order, 15 August 1997, 13 May 2004). Notably, text in Russian must be situated on the left side of a signboard or document.

In Mari El, the texts of documents, namely, document forms, seals, stamps and signboards with the names of authorities and organizations are written in the state languages, but it is also permitted to provide additional translations into local languages (article 26). This is one of the few provisions that are really used in practice. Short official texts, such as the names of authorities, are given in two languages. This could be explained as a remnant of the Soviet-era practices of "transparent" recognition of the multinational character of the state with the domination of a "façade" of cultural traditions. In Mari El, documents testifying the identity of a citizen and other information such as passports, birth, marriage, death and education certificates, diplomas, and other documents "can be issued in both state languages" (article 28). Military cards are not mentioned.

In Udmurtia, the texts of documents, namely, document forms, seals, stamps and signboards with names of authorities and organizations are written in the state languages (article 18). It is stated in the language law of Udmurtia that documents testifying the identity of a citizen and other information such as passports, birth, marriage, death and education certificates, diplomas, military cards and other documents are issued in Russian and can be issued also in Udmurt in the order defined by the legislation (article 18). In Mordovia, texts of seals, stamps and document forms of state authorities are written in the state languages of the Republic of Mordovia (article 19). Official documents testifying the identity of a citizen and other information, including birth, marriage, death and education certificates (except from federal education institutions), are being issued in the state languages (article 18). In Karelia, texts documents (document forms, seals, stamps) of executive and municipal authorities, legal entities, according to their regulations or statutes, can be written in the Karelian, Veps and (or) Finnish languages alongside Russian (article 8). 
The joint data on language use in communication with citizens are presented in Table 2. Titular languages are used in communication with citizens to a somewhat larger extent than in office. However, the issue of identity documents is an example of how problematic the enactment of a provision can be, and how this depends on further actions of the authorities. One of the layers of the new Russian nationalities policy was the strife to exclude the Soviet practice of ascribing ethnicity to individuals, indicating person's ethnicity in documents testifying personal identity. The federal law on the acts of civil status demanded the use of Russian and the state languages of the republics (Federal Law, 15 November 1997). According to this federal law, authorities mark the ethnicity (nationality - in Russian) of a citizen in identity documents only if s/he wishes so. Recently it was reported by media that only about ten percent of Russia's population has a passport in the proper sense, that is, a document which among other things allows its holder to travel abroad, referred in Russian as a "foreign passport". Instead, citizens have a domestic identity document, which is called a "passport" or "civil passport", and which is discussed further here. According to the regulation on issuing passports (RF Government Decree, 8 July 1997), an additional leaf can be issued in the passport in the republics in the republican state languages. Issuing of this leaf began in 2001, but only in Bashkortostan and Tatarstan (Sokolov 2002: 215-216).

In 2004, the President of Mari El addressed the republican state authorities with the demand to start issuing an additional leaf in passports in the state languages of the republic. The republican Department of the Federal Migration Service (FMS), which is authorized to issue passports, responded that it is not a republican but a federal authority and that issuing the additional leaf was not within its competence. The republican Ministry of Internal Affairs gave a similar justification for the rejection. As there was no positive response, a citizen went to court against the republican Ministry of Internal Affairs. The court acknowledged the lawfulness of his demand and pointed out that it is an obligation of the republican executive authorities to develop the form of the additional leaf (Yoshkar-Ola Court Judgment, 23 March 2004). Both authorities involved readdressed the matter to the republican President, who is simultaneously the head of the republican government (RME Ministry Communication, 12 November 2004, FMS Department Communication 10 October 2007). The republican government admitted in its response to the FMS Depart- 


\section{Republic}

Komi

Mari El

Language law

(a) Administration of justice, legal proceedings, notarial management

(b) Languages of elections and referenda 1995, amended 2001, 2008, 2009, 2011

1992, amended 2002, 2009

1992: court proceedings and state notarial management had to be performed in Komi and Russian. 2002: it is regulated by federal legislation.

1992: Komi and Russian had to be used in arrangement and completion of elections and referenda at all levels. 2002: bulletins printed in Komi and Russian by decision of election or referendum committee according to federal and republican legislation.
Administration of justice and court proceedings in the Constitutional Court and other courts in the republic are carried out in the Mari and Russian languages. 1995: Mari (Hill, Meadow) and Russian, but also other local languages "are used" in arrangement and completion of the republican and municipal elections and referenda. Bulletins are published in Russian with translation into the Mari languages and, if necessary, into other local languages by decision of the election or referendum commission. 2009: the republican state languages and other local languages.

1992: citizens have the right to make requests to authorities and legal entities in the Komi and (or) Russian languages. Authorities address citizens in Komi or Russian, depending on the citizen' wishes.

2002: right to make requests to authorities also in other languages of the peoples of Russia. Answers are provided in the language of the request or in the state languages. (d) Documents of authorities
Names of legal entities, texts of official seals, stamps, document forms and advertisements are written in Komi and Russian.
A citizen has the right to choose for oral information to be provided and documents issued in one of the state languages of the Republic of Mari El, or also other local languages. 1995: "state and municipal authorities, organizations, and their officials, respond to written request of citizens in the language of the request". 2001: the obligation to provide a response in the republican state languages or in Russian.

2008: the responses are given in the language of the request, "unless it is impossible".

Texts of documents are written in the republican state languages; it is also permitted to provide additional translation into local languages.
Official documents testifying identity of a citizen and other information
1992: in Komi and Russian.

2002: in Komi and Russian according to federal legislation.
Documents "can be issued in both state languages". 


\begin{tabular}{|c|c|c|}
\hline Mordovia & Udmurtia & Karelia \\
\hline 1998, amended 2010 & 2001, amended 2010 & 2004 \\
\hline $\begin{array}{l}\text { 1998: legal proceedings and } \\
\text { notarial management are in } \\
\text { Russian and, if needed, in } \\
\text { Mordvin (Moksha or Erzya). } \\
\text { 2010: provision excluded. }\end{array}$ & $\begin{array}{l}\text { No provision in this } \\
\text { sphere except for notarial } \\
\text { management, where } \\
\text { documents can be issued in } \\
\text { either of the state languages. }\end{array}$ & No provision. \\
\hline $\begin{array}{l}\text { The Russian and Mordvin } \\
\text { (Moksha or Erzya) languages } \\
\text { "are used" in the arrangement } \\
\text { and completion of republican } \\
\text { elections and referenda. } \\
\text { Bulletins are published in } \\
\text { Russian, but some bulletins } \\
\text { can be published by decision } \\
\text { of the election or referendum } \\
\text { commission in both the } \\
\text { Russian and Mordvin (Moksha } \\
\text { or Erzya) languages. }\end{array}$ & $\begin{array}{l}\text { The republican state } \\
\text { languages "are used" in the } \\
\text { arrangement and completion } \\
\text { of federal, republican and } \\
\text { municipal elections and } \\
\text { referenda, whereas other } \\
\text { local languages can be used. } \\
\text { Bulletins are published in } \\
\text { Russian, although they can } \\
\text { be published in Russian and } \\
\text { Udmurt and, if necessary, } \\
\text { in other local languages by } \\
\text { decision of the election or } \\
\text { referendum commission. }\end{array}$ & $\begin{array}{l}\text { Russian; the Karelian, Veps } \\
\text { and (or) Finnish languages can } \\
\text { be used in the territories the } \\
\text { speakers of these languages } \\
\text { live in arrangement and } \\
\text { completion of republican } \\
\text { elections and referenda on } \\
\text { the issues touching human } \\
\text { rights and citizens' obligations } \\
\text { as well as in bulletins by } \\
\text { decision of the election or } \\
\text { referendum commission. }\end{array}$ \\
\hline $\begin{array}{l}\text { 1998: Russian or Mordvin } \\
\text { (Moksha or Erzya) are used in } \\
\text { the relations of authorities and } \\
\text { legal entities with citizens. } \\
\text { 2010: citizens are free } \\
\text { to choose the language } \\
\text { of communication with } \\
\text { authorities and municipalities. }\end{array}$ & $\begin{array}{l}\text { Citizens have the right to } \\
\text { make requests to republican } \\
\text { and municipal authorities and } \\
\text { legal entities in the republican } \\
\text { state languages. Responses } \\
\text { are given in the language of } \\
\text { the request or, "in case of } \\
\text { impossibility", in Russian. }\end{array}$ & No separate provision. \\
\hline $\begin{array}{l}\text { Texts of seals, stamps and } \\
\text { document forms of state } \\
\text { authorities are written in } \\
\text { the state languages. }\end{array}$ & $\begin{array}{l}\text { Texts of documents are } \\
\text { written in the republican } \\
\text { state languages. }\end{array}$ & $\begin{array}{l}\text { Texts documents (document } \\
\text { forms, seals, stamps) of } \\
\text { executive and municipal } \\
\text { authorities, legal entities can be } \\
\text { written in the Karelian, Veps } \\
\text { and (or) Finnish languages. }\end{array}$ \\
\hline In the state languages. & $\begin{array}{l}\text { Documents are issued in } \\
\text { Russian and can be issued } \\
\text { also in Udmurt in the order } \\
\text { defined by the legislation. }\end{array}$ & No separate provision. \\
\hline
\end{tabular}




\section{Konstantin Zamyatin}

ment that the republics indeed have the right to introduce the additional leaf in passports in the republican state languages, but stated without further clarification that currently "the matter is not under the government's consideration" (RME Government Communication, 16 November 2007). In 2008 the FMS Department filed an action with the court for suspension of the 2004 court judgment and in 2010 for reversal of the 2004 court judgment with the argument that in 2004, it was not the FMS Department but the Passports and Visas Service of the Ministry of Internal Affairs that was authorized to issue passports. The court, in its rulings, satisfied in 2007 the FMS Department request to change the plaintiff, suspended in the 2008 implementation of its 2004 judgment and refused in 2010 to satisfy the demand of the citizen to stop suspension of issuing an additional leaf (RME Yoshkar-Ola Town Court Rulings, 27 April 2007, 14 January 2008, 15 April 2010; see Ivanova 2010).

\section{The languages of public services and other public communications}

Activities of legal entities providing public services constitute another important domain of official language use. In line with federal legislation, the according provisions in the republican language laws prescribe the compulsory usage of the state languages of the republics in the activities of legal entities that provide (a) general public services, (b) consumer services and commercial activities, (c) audio-visual information and advertisements, and (d) geographical objects.

(a) According to Russia's language law, Russian and on certain occasions other languages are used in the sphere of industry, communication, transport and power engineering, while state languages of republics can be used on account of interests of the local population (article 21). In Komi, there has been no separate provision on language use in public services. Document circulation within legal entities previously had to be performed in one of the state languages (article 15). However, after an amendment made in 2002, it is performed in the order defined by federal legislation. In Mari El, the republican state languages "are used" in all of these spheres of public communications (article 35). The republican state languages and other languages were to be used in the document circulation of legal entities (article 37), but this provision was excluded in the 2001 amendment. In Udmurtia, communications of legal entities are regulated only by a gen- 
eral statement that Russian "is used" in industry, agriculture, communications, transport and power engineering; Udmurt is used if there is a need for it (article 22). In Mordovia, there is no separate provision on language use in public services. The document circulation of legal entities is performed in Russian. The Mordvin (Moksha or Erzya) language can also be used, if necessary (article 17).

(b) According to Russia's language law, Russian and other languages are used in the sphere of services and commercial activity (article 22). In Komi, citizens have the right to choose the state language in providing consumer services and pursuing commercial activity (article 5). With the 2002 amendment, this right was expanded to any language. However, if communication in the chosen language is impossible, the state languages are used. Concerning language use in consumer services and commercial activity in Mari El, it "is defined" by the order in the legislation. Refusal to providing consumer services in any republican state language because of a lack of their knowledge is counted as illegal and "is to be" punished according to the federal and republican legislations (article 36). For this concrete provision, responsibility is measured by Russia's law (Law RF, 7 February 1992, article 12). In Udmurtia, the republican state languages "are used" in consumer services and commercial activity (article 23). In Mordovia, there is no separate provision on language use in consumer services and commercial activity, but it is noted that information such as labels, standards, nomenclature and instructions on goods manufactured in Mordovia are provided in Russian and, if needed, in Mordvin (Moksha or Erzya) (article 20).

(c) Russia's language law contained no separate regulation on audio-visual information and advertising. In Komi, advertisements are carried out in Komi and Russian; public information is given in the state languages (article 25). Square and street names are given in Komi and Russian (article 23). The instruction letter of the Ministry for Nationalities Affairs approved the rules on making the design of signboards with street names and square names in towns and settlements of the Komi Republic. In Mari El, street names are given in the republican state languages (article 52); this provision had to be implemented within one year (article 60). Marking of goods, labels, standards, nomenclatures, instructions of goods manufactured in the republic (article 54); texts of official announcements, 


\section{Konstantin Zamyatin}

information, visual and auditory advertisements, and other information, such as timetables, auditory and visual announcements in airports, railway stations, river ports and bus stations, are duplicated in the republican state languages (article 53). A government decree is being drafted, which would approve the regulation on language use in the publication of socially significant information and advertisements in the Republic of Mari El. In the language laws of Udmurtia and Mordovia, there is no separate provision on audio-visual information and advertisements. The Mordovian law states in addition that "traditional square and street names are maintained" (article 23).

From the perspective of language landscapes, in Syktyvkar, the capital of Komi, and Yoshkar-Ola, the capital of Mari El, street names are normally written in two languages. Izhevsk, the capital city of Udmurtia, Saransk, the capital of Mordovia and Petrozavodsk, the capital of Karelia, bear only few visual and auditory marks that they are not the capital cities of ordinary oblasts, but in fact of ethnic republics. These are signs indicating the names of the republican authorities and announcements at a few tram stops. Generally, in towns, one can only rarely hear auditory information or people speaking other languages than Russian.

(d) Regarding the language of titles of geographical objects, inscriptions, road and other signs, they are installed in Russian, but the state languages of republics and other local languages can be used (article 23). What is remarkable is that the setting up of the road signs is the only duty put on the federal and regional authorities by Russia's language law (article 24). A separate regulation was passed that demanded the use of the state language of the whole country or state languages of the republics in marking objects of cultural heritage (Federal Law, 25 June 2002, article 27).

In Komi, measures for the maintenance of traditional geographical names are being taken. Road and other public signs are installed in Komi and Russian (article 23). In 2002, a provision was added that ensures installation and maintenance of public signs according to the order defined in federal and republican legislation. The government approved the rules for writing geographical names in the Komi language and created a commission for this purpose (KR Government Decree, 18 October 2004, 24 February 2009). Information signs on objects of cultural heritage have to be written in the Komi and Russian languages (Law LR, 21 May 2004, article 8). In Mari El, traditional local geographic names of historical and cul- 
tural value "are maintained" (article 50). A corresponding regulation on information signs on objects of cultural heritage was passed demanding the use of the Russian and Mari languages (RME Government Decree, 14 December 2008). In Udmurtia, "names of geographical objects and installation of bilingual road signs, street signs and other public signs have to be given in the republican state languages according to the order defined by the legislation". Symptomatically for language attitudes, "the text in Russian has to be written on the left and above, in Udmurt on the right and below" (article 26). The government decree approved the order for making the design of the names of geographical objects and installation of bilingual road signs, street signs and other public signs (UR Government Decree, 7 November 2005). In Mordovia, the government defines the list of geographical objects for which names and signs have to be provided in two or three state languages of the republic or in other local languages (article 23). This is the only provision in the law in which Moksha and Erzya are recognized as the separate languages. The republican executive authorities are responsible for the installation and maintenance of public signs according to federal and republican legislation (article 24). In Karelia, measures are being taken for the maintenance of names of geographical objects of historical and ethno-cultural heritage. Road and other public signs can be installed in the Karelian, Veps and (or) Finnish languages along with Russian in the territories where speakers of these languages live compactly (article 11).

The joint data on language use in public services are presented in Table 3. Public communications and public services are closer to citizens than the working language of authorities; they contribute to the formation of language landscapes. It is often only the civil initiative of citizens that can set in motion many legal provisions concerning services and communication. For instance, in the Republic of Mari El, citizens addressed authorities on the issue concerning passports, but also with other demands, such as addresses to the Russian railways company with the demand to transmit music in the Mari language in the trains with circulation Moscow-Yoshkar-Ola and an address to support the printing of postcards in the state languages. Notably, there is no general citizen's right to use the state languages before authority. The right to receive information from the state authorities and public organizations is not ensured by the language laws, but by the federal law. 


\begin{tabular}{|c|c|c|}
\hline Republic & Komi & Mari El \\
\hline Language law & 1992, amended 2002, 2009 & $\begin{array}{l}\text { 1995, amended 2001, } \\
\text { 2008, 2009, } 2011\end{array}$ \\
\hline $\begin{array}{l}\text { (a) Language of } \\
\text { public services }\end{array}$ & $\begin{array}{l}\text { No separate provision } \\
\text { on language use in } \\
\text { public services. } \\
\text { 1992: the document circulation } \\
\text { of legal entities performed in } \\
\text { one of the state languages. } \\
\text { 2002: it is performed } \\
\text { in the order defined by } \\
\text { federal legislation. }\end{array}$ & $\begin{array}{l}\text { The republican state } \\
\text { languages "are used" in } \\
\text { industry, communications, } \\
\text { transport, and power } \\
\text { engineering, agriculture } \\
\text { and consumer services. } \\
\text { 1995: the republican state } \\
\text { languages and other languages } \\
\text { "are used" in the document } \\
\text { circulation of legal entities. } \\
\text { 2oo1: latter excluded. }\end{array}$ \\
\hline $\begin{array}{l}\text { (b) Languages } \\
\text { in consumer } \\
\text { services and } \\
\text { commercial } \\
\text { activities }\end{array}$ & $\begin{array}{l}\text { 1992: the right of citizens to } \\
\text { choose the state languages in } \\
\text { enjoying consumer services } \\
\text { and commercial activities. } \\
\text { Individuals, who create } \\
\text { obstacles for the choice } \\
\text { of the state languages for } \\
\text { communications, bear } \\
\text { responsibility according } \\
\text { to defined order. } \\
\text { 2oo2: this right and } \\
\text { responsibility expanded to } \\
\text { any language. However, if } \\
\text { communication in the chosen } \\
\text { language is impossible, the } \\
\text { state languages are used. }\end{array}$ & $\begin{array}{l}\text { Marking of goods, labels, } \\
\text { standards, nomenclatures, } \\
\text { instructions of } \\
\text { manufactured goods. } \\
\text { 2008: the order of language } \\
\text { use in consumer services } \\
\text { and commercial activities "is } \\
\text { defined" by the legislation. } \\
\text { Refusal to provide consumer } \\
\text { services in any republican } \\
\text { state language because of } \\
\text { lack of their knowledge } \\
\text { was counted as illegal } \\
\text { and "is to be punished" } \\
\text { according to the federal and } \\
\text { republican legislations. }\end{array}$ \\
\hline $\begin{array}{l}\text { (c) Languages } \\
\text { of audio-visual } \\
\text { information and } \\
\text { advertisements }\end{array}$ & $\begin{array}{l}\text { Advertisements are produced } \\
\text { in Komi and Russian; public } \\
\text { information is provided in } \\
\text { the state languages. Square } \\
\text { and street names are written } \\
\text { in Komi and Russian. }\end{array}$ & $\begin{array}{l}\text { Names of streets are written } \\
\text { in the republican state } \\
\text { languages; texts of official } \\
\text { announcements, information, } \\
\text { visual and auditory } \\
\text { advertisements, as well as } \\
\text { other information, timetables } \\
\text { and announcements are } \\
\text { duplicated in the republican } \\
\text { state languages. }\end{array}$ \\
\hline $\begin{array}{l}\text { (d) Names of } \\
\text { geographical } \\
\text { objects }\end{array}$ & $\begin{array}{l}\text { Measures for the maintenance } \\
\text { of traditional geographical } \\
\text { names are being taken. Road } \\
\text { and other public signs are } \\
\text { installed in Komi and Russian. }\end{array}$ & $\begin{array}{l}\text { Traditional local geographic } \\
\text { names of historical and } \\
\text { cultural value are maintained. }\end{array}$ \\
\hline
\end{tabular}




\begin{tabular}{|c|c|c|}
\hline Mordovia & Udmurtia & Karelia \\
\hline 1998, amended 2010 & 2001, amended 2010 & 2004 \\
\hline $\begin{array}{l}\text { No separate provision on } \\
\text { language use in public } \\
\text { services. The document } \\
\text { circulation of legal entities } \\
\text { is performed in Russian. } \\
\text { The Mordvin (Moksha or } \\
\text { Erzya) language can also } \\
\text { be used, if necessary. }\end{array}$ & $\begin{array}{l}\text { Russian "is used" in industry, } \\
\text { agriculture, communications, } \\
\text { transport, and power } \\
\text { engineering; Udmurt is } \\
\text { used if there is need for it. }\end{array}$ & No separate provision. \\
\hline $\begin{array}{l}\text { No separate provision on } \\
\text { language use in consumer } \\
\text { services and commercial } \\
\text { activities. Labels, standards, } \\
\text { nomenclature of goods } \\
\text { manufactured in Mordovia } \\
\text { and instructions are provided } \\
\text { in Russian and, if needed, in } \\
\text { Mordvin (Moksha or Erzya). }\end{array}$ & $\begin{array}{l}\text { The republican state } \\
\text { languages "are used" in } \\
\text { consumer services and } \\
\text { commercial activities. }\end{array}$ & No separate provision. \\
\hline $\begin{array}{l}\text { No separate provision. } \\
\text { Traditional square and street } \\
\text { names are maintained. }\end{array}$ & No separate provision. & $\begin{array}{l}\text { Texts of documents } \\
\text { (document forms, seals, } \\
\text { stamps) of executive and } \\
\text { municipal authorities } \\
\text { as well as legal entities } \\
\text { can be accomplished the } \\
\text { Karelian, Veps and (or) } \\
\text { Finnish languages. }\end{array}$ \\
\hline $\begin{array}{l}\text { The government defines the } \\
\text { list of geographical objects } \\
\text { for which the names and } \\
\text { signs have to be provided } \\
\text { in two or three state } \\
\text { languages of the republic or } \\
\text { in other local languages. }\end{array}$ & $\begin{array}{l}\text { Names of geographical } \\
\text { objects and installation } \\
\text { of public signs in the } \\
\text { republican state languages. } \\
\text { The government decree } \\
\text { approved the order. }\end{array}$ & $\begin{array}{l}\text { Measures for the maintenance } \\
\text { of names of geographical } \\
\text { objects are being taken. Road } \\
\text { and other public signs can be } \\
\text { installed in the Karelian, Veps } \\
\text { and (or) Finnish languages. }\end{array}$ \\
\hline
\end{tabular}




\section{The official languages in the work environment and language preferences}

Some public services are so important that they are divided in separate domains of language use in this study: official languages in the work environment, official mass media and public education. The first of these domains is considered in this section and two others in the next section.

The term "language preferences" refers to an obligation for workers of some professions to know the language, for example those in the spheres of sale, transport, culture, education and other spheres of communication with the population. The list of professions requiring knowledge of the state languages to ensure the proportional representation of main ethnic groups among civil servants and the list of language command qualifications are sometimes adopted by the state authorities. Russia's language law allowed certain restrictions and norms for the use of languages in the sphere of professional communication envisaged by the introduction of language qualification requirements (article 15). The language command by officials and civil servants is needed for ensuring the right of citizens to address the state authorities in the state languages, as well as to provide public services, including mass media and public education.

The domain of language use in office of enterprises, organizations and other legal entities lies on the border of the private and public sphere. Will Kymlicka considers this domain to be even more important than the domain of communication of citizens with state authorities, because "people only interact with the state on the episodic basis. The real key to the reproduction of the societal culture is the ability to use one's language in one's day-to-day employment". Language use in the work environment is important both in the private and public sector, because "the government is a very large employer" (2001: 156-157). The official status serves as a tool for promoting the use of a certain language in work environments in the public sector. This is done, among other means, through the introduction of language preferences. There is also a general principle of non-discrimination of the basis of language. This is why the introduction of language preferences has to be justified by the need to provide public services in a language that is comprehensible to the population.

Because state authorities are also employers, labour relations should be considered an important part of the work environment. An important type of language preference is the demand for the knowledge of the state languages by officials in all branches of power: the head of the republic, 
members of republican parliaments, government officials and civil servants. This element of the domain is conjoined with the domain of working languages of authorities and the domain of public communications for the part of elections. The peculiarity of language preferences in the work environment is that language requirements are presented as a prerequisite for the establishment of labour relations.

As was noted, Russia's Constitutional Court found unconstitutional language requirements for head of republic (RF Constitutional Court Judgment, 27 April 1998). All state servants in Russia (civil, law enforcement and military servants) are obliged to know the state language of the Russian Federation (Federal Law, 31 July 1995, article 21; article 12, Federal Law, 27 May 2003; Federal Law, 27 July 2004, article 21; Federal Law, 2 March 2007, article 4).

In Komi, the absence of knowledge of one of the state languages cannot be a reason for denial of work. It is further stated that language knowledge does not create preferences in any activities, including administration. However, the list of professions demanding the knowledge of both state languages and other languages had to be defined in the state authorities by the republican Supreme Council and in legal entities by the professional instruction (article 18). The 2002 amendment excluded the provision demanding language knowledge. Heads of state authorities were obliged to create conditions for acquiring the minimum knowledge needed for work by all civil servants (article 13). With the 2002 amendment, municipalities were charged with this obligation, too. However, with the 2009 amendment, the obligation of municipalities was excluded from the provision (Law KR, 6 July 2009). There are no language requirements among the general qualification requirements for civil servants in the republican administrative and labour legislation (Law KR, 25 March 1996, 5 March 2005, 21 December 2007).

In Mari El, the language law has a provision that state officials and civil servants must have command of Russian and also of one of the republican state languages, that is, Meadow Mari or Hill Mari, to the extent needed to carry out their professional duties (article 14). There is also a specific language preference in the language law stating that "heads and employees of education institutions are chosen taking into account knowledge of the languages of the institution" (article 39). Otherwise, in the Mari El legislation, there are no language requirements among the general qualification requirements for civil servants (Law RME, 23 February 1995, 7 April 1998). 


\section{Konstantin Zamyatin}

In Udmurtia, there are no provisions on language preferences in the language law. There used to be a provision that citizens with knowledge of one or two state languages of the Udmurt Republic could enter the civil service (Law UR, 26 November 1997, Article 24). However, the new law does not contain a corresponding provision (Law UR, 5 July 2005, 25 February 1999).

In Mordovia, there are no language preferences either in the language law or in other pieces of legislation (Law RM, 26 January 1996, 28 May 1999). In Karelia there are no language preferences either in the language law or in other pieces of legislation (Law RK, 5 December 1996, 10 January 1997). The culture law established bonuses for the usage of the Karelian, Veps and Finnish languages by workers in libraries, museums, archives, radio, TV, printing houses and other institutions (Law RK, 24 January 1995, article 44). The education departments of municipalities received the right to introduce bonuses for teachers of native languages up to $50 \%$, not by the law, but by the department act (RK State Committee Communication, 17 February 1993).

Therefore, in the republics there are no additional language preferences either for parliament members or for civil servants in the constitutional, administrative and labour legislations of the republics. This is justified by the federal legal provision on the prohibition of discrimination based on language. Financial bonuses for the knowledge of the state languages are provided by Chuvashia's language law (article 3). In Tatarstan, there is still a plan to introduce language preferences and to adopt language qualification minimums as well as financial bonuses to salaries for practical usage of the state languages at work.

\section{The official languages in mass media and education}

Official mass media are the central channel for communication of the state authorities with citizens. At the same time, national movements use mass media for reinforcement of collective identities (Cormack 2000: 383). This is why the use of minority languages by mass media is an important element of the ethno-political balance. On the level of language ideology, the multinational character of the federal state and the federation units had to be emphasized. Russia's language law states that publication of all-Russian print mass media as well as TV and radio broadcasting are conducted in Russian, while other languages can also be used according to the will of the founders (article 20). 
In Komi, the publication of periodicals as well as TV and radio broadcasting are carried out in Komi and Russian (article 22). The 2002 amendment weakened this provision in such a manner that the publication of periodicals, TV and radio broadcasting are carried out in Komi "and (or)" Russian. The provision was added that the republican mass media have the right to use other languages of the peoples living in the Komi Republic. In Mari El, distribution of information for the public in the republic must be provided in the republican state languages (article 47), and the republican TV and radio broadcasting is performed in the republican state languages (article 48). Additionally, the republic ensures priority to the publication of periodicals in the "languages, which demand the state support for their development", that is in the Mari languages (article 44), and to the translation of movies, audio and video materials into the Mari languages (article 45). The language law of Udmurtia states only that in mass media, the republican state languages and other languages are used, including in translations and dubbing of TV and radio programs (article 21). According to the language law of Mordovia, mass media (radio, TV, print) ensure the usage of the state languages and take into account the needs of individuals of other nationalities (article 21). In Karelia, state and municipal authorities create conditions for the functioning of mass media in the Karelian, Veps and Finnish languages (article 9). These languages can be used through translation and dubbing of TV and other visual production (article 10).

Since the Soviet time, education has probably been the only domain where the use of titular languages was relatively well maintained (see $\mathrm{Za}$ myatin 2014a: 104). Russia's language law establishes three modes of language teaching: as the language of instruction, as the native language as a subject, and as the state language as a subject (article 9; see Zamyatin 2012a for a comprehensive study on minority language education in Russia).

In Komi, Komi and Russian must be taught as the state languages of the republic in all primary and secondary schools (article 19). At the same time, Komi is not used as the language of instruction and is taught in its capacity of native language only as a subject. In Mari El, Mari and Russian were made to be studied as the state languages are in all republican education institutions (article 11). In addition, Mari was both taught as native language and also functioned as the language of instruction until the 2001 amendment. In Udmurtia, Udmurt was not made compulsory for study by all students as the state language and is taught only as a subject in the 
capacity of native language (article 7). In Mordovia, the study of the state languages was introduced as optional (article 10). Erzya and Moksha are used as the languages of instruction in rural primary schools. In Karelia, the Karelian, Veps and Finnish languages can be studied as native language subjects (article 5; see Zamyatin 2012b and 2012c for a comprehensive study on the position of titular languages in the school systems of the Finno-Ugric republics).

The joint data on language use in work environment, mass media and education are presented in Table 4. Regarding mass media, the legal provisions did not change much in the real situation because of their vague character. At the same time, many periodicals have internet versions, often also translated into the titular languages. However, as was stated above, there are still not many regulations for this sphere in the republican legislations. Regarding education, since the entering into force of a new Federal Education Law, the expansion of compulsory teaching of titular languages as the state languages of the republic is no longer on the agenda, and teaching of native languages is on the retreat (Federal Law, 29 December 2012).

\section{Deficiencies of the laws that undermine official bilingualism}

The formal justification for the language laws was the need to create a legal basis for the republican authorities to implement the language policies and to ensure protection of individual language rights in the new conditions of a democratic society. However, the original idea behind the status planning in the republics, backed by ethnic elites, was to create a foundation for the expansion of titular languages. However, ethnic elites had to negotiate and compromise their claims with regional Russian elites, who saw their interest in symbolic recognition of languages as a way to support their claim for more regionalism but were unwilling to support the expansion. The reluctance of the Russian elites was grounded in their majority language ideologies, including the assumption of "efficiency", that one language best serves the functionality of the state apparatus, the assumption that the state's "integrity" is best served on a precondition of one language, and the assumption that "progress" inevitably leads to language loss (see Blommaert 1996: 210-212, Patrick 2010: 181-183). The findings of the current study contribute to the conclusion of the previous study that found a correlation between the relative strength of ethnic elites and the level of institutionalization of titular languages (Zamyatin 2013c: 140-143). 
Already the fact that the language law of Mari El is twice as thick as the other language laws demonstrates an exceptional attitude of the legislator towards the promotion of the titular language in this republic.

Regarding their scope, the language laws in Komi and Mordovia are focused on their state languages. Concerning other languages, it was noted that, according to Russia's language law, languages of compactly living minorities can perform some official functions in municipalities according to regional legislations. This possibility was provided for other languages from the beginning, e. g. in the republics of Bashkortostan and Sakha, but not in the republics under consideration. Yet, also in the laws of the latter ones, some elements of the official status were introduced for other languages, e. g. local languages can be used in the arrangement and holding of elections and referenda. The language laws in Udmurtia and Mari El have a wider scope of application, which includes not only the state languages of the republics, but also the other "languages of the peoples of the republic". Nevertheless, also in these laws most provisions regulate exclusively the official status of their state languages. The laws provide the state languages with some important possibilities concerning their use in administrative issues, in education, and in other domains. The scope and configuration of the public domains can be traced back to the common framework for the republican language laws, which was Russia's language law (see Zamyatin 2013c: 143). Similarly, regarding the content, there are only few provisions on corpus planning and prestige planning for the titular languages in the laws, as these aspects of language planning are practically absent in Russia's law.

Karelia is an interesting case, as the titular language was not designated as the state languages of the republic. However, the analysis demonstrated that the actual domains of language use are not so different from those in the other republics. As in the other republics, the Karelian Law recognizes the right of free choice of the language of instruction, the right to learn the Karelian, Veps and Finnish languages and to receive education in these languages (article 5). These languages can be used in publication of laws and other legal acts in the Republic of Karelia (article 6), in arranging and holding of elections and referenda on the territory of Karelia (article 7), can be used by state and municipal authorities, public institutions (article 8) and mass media (article 9), in the fields of culture, arts and education (article 10), in names of geographical objects, road and other signs (article 11). Therefore, the absence of the status of state language did not automati- 


\begin{tabular}{|c|c|c|}
\hline Republic & Komi & Mari El \\
\hline Language law & 1992, amended 2002, 2009 & $\begin{array}{l}\text { 1995, amended 2001, } \\
\text { 2008, 2009, } 2011\end{array}$ \\
\hline $\begin{array}{l}\text { The official } \\
\text { languages } \\
\text { in work } \\
\text { environment } \\
\text { and language } \\
\text { preferences }\end{array}$ & $\begin{array}{l}\text { 1992: the list of professions } \\
\text { requiring the knowledge } \\
\text { of both state languages and } \\
\text { other languages in the state } \\
\text { authorities had to be defined. } \\
\text { 20o2: no list provided. } \\
\text { An obligation for the heads of } \\
\text { authorities and municipalities to } \\
\text { create conditions for acquiring } \\
\text { the minimum knowledge required } \\
\text { for work by all servants. } \\
\text { 2oog: no obligation for } \\
\text { municipalities. }\end{array}$ & $\begin{array}{l}\text { State officials and civil servants } \\
\text { must have command of Russian } \\
\text { and also of one of the republican } \\
\text { state languages, that is, Meadow } \\
\text { Mari or Hill Mari, to the extent } \\
\text { required to carry out their } \\
\text { professional duties. "Heads } \\
\text { and employees of education } \\
\text { institutions are chosen taking } \\
\text { into account knowledge of the } \\
\text { languages of the institution". }\end{array}$ \\
\hline $\begin{array}{l}\text { The official } \\
\text { languages in } \\
\text { mass media }\end{array}$ & $\begin{array}{l}\text { 1992: publication of periodicals, } \\
\text { TV and radio broadcasting are } \\
\text { carried out in Komi and Russian. } \\
\text { 2002: publication of periodicals, } \\
\text { TV and radio broadcasting are } \\
\text { carried out in Komi "and (or)" } \\
\text { Russian. The republican mass } \\
\text { media have the right to use } \\
\text { other languages of the peoples } \\
\text { living in the Komi Republic. }\end{array}$ & $\begin{array}{l}\text { Distribution of public information } \\
\text { in the republic must be carried out } \\
\text { in the republican state languages; } \\
\text { the republican TV and radio } \\
\text { broadcasting is performed in } \\
\text { the republican state languages. } \\
\text { Additionally, the republic ensures } \\
\text { priority to the publication of } \\
\text { periodicals in the "languages, } \\
\text { which demand the state support } \\
\text { for their development" and } \\
\text { the translation of movies, } \\
\text { audio and video materials } \\
\text { into the Mari languages. }\end{array}$ \\
\hline $\begin{array}{l}\text { The official } \\
\text { languages in } \\
\text { education }\end{array}$ & $\begin{array}{l}\text { The right to choose the language } \\
\text { of upbringing and instruction. } \\
\text { The state languages, Komi and } \\
\text { Russian, are studied in all schools. } \\
\text { 1992: the right to choose } \\
\text { Komi or Russian for entering } \\
\text { high professional, higher } \\
\text { education institutions and } \\
\text { accomplishing research. } \\
\text { 2oog: languages of upbringing } \\
\text { and instruction are defined } \\
\text { by the founder of the } \\
\text { educational institution. }\end{array}$ & $\begin{array}{l}\text { The right to choose freely the } \\
\text { language of upbringing and } \\
\text { instruction; the equal right } \\
\text { to receive education in one's } \\
\text { chosen native language. Free } \\
\text { choice of education institution, } \\
\text { but also by the demand that } \\
\text { Mari and Russian as the state } \\
\text { languages are studied in all } \\
\text { republican education institutions. } \\
\text { The right to "pass exams in } \\
\text { one of the state languages". }\end{array}$ \\
\hline
\end{tabular}

Table 4: The official languages in work environment, official mass media and public education 


\begin{tabular}{|c|c|c|}
\hline Mordovia & Udmurtia & Karelia \\
\hline 1998, amended 2010 & 2001, amended 2010 & 2004 \\
\hline No language preferences. & No language preferences. & No language preferences. \\
\hline $\begin{array}{l}\text { Mass media (radio, TV, } \\
\text { print) ensure the usage } \\
\text { of the state languages } \\
\text { and take into account } \\
\text { the needs of individuals } \\
\text { of other nationalities. }\end{array}$ & $\begin{array}{l}\text { In mass media, the republican } \\
\text { state languages and other } \\
\text { languages are used, including } \\
\text { translations and dubbing of } \\
\text { TV and radio programs. }\end{array}$ & $\begin{array}{l}\text { State and municipal } \\
\text { authorities create conditions } \\
\text { for the functioning of mass } \\
\text { media in the Karelian, Veps } \\
\text { and Finnish languages. } \\
\text { These languages can be } \\
\text { used by translation and } \\
\text { dubbing of TV and other } \\
\text { visual production. }\end{array}$ \\
\hline $\begin{array}{l}\text { Parents have the right } \\
\text { to choose the language } \\
\text { of instruction according } \\
\text { to federal legislation. } \\
\text { 1998: the right to pass the } \\
\text { entrance exams of high } \\
\text { professional and higher } \\
\text { education institutions in } \\
\text { Mordvin (Moksha or Erzya). } \\
\text { 2010: the republic creates } \\
\text { the conditions for citizens to } \\
\text { learn the state languages and } \\
\text { other languages of compactly } \\
\text { living groups within the } \\
\text { potentialities provided by } \\
\text { the education system. }\end{array}$ & $\begin{array}{l}\text { The right of citizens to } \\
\text { choose freely the language of } \\
\text { upbringing and instruction. } \\
\text { This right and the right to } \\
\text { receive pre-school, primary } \\
\text { and secondary school } \\
\text { education in one's native } \\
\text { language are restricted to } \\
\text { the potentialities provided } \\
\text { by the education system. } \\
\text { Creation and support of } \\
\text { national schools, classes } \\
\text { and groups. Russian and } \\
\text { Udmurt as the state languages } \\
\text { are studied as subjects } \\
\text { "according to the legislation". }\end{array}$ & $\begin{array}{l}\text { The Karelian, Veps and } \\
\text { Finnish languages can } \\
\text { be studied as subjects in } \\
\text { educational institutions } \\
\text { according to federal and } \\
\text { republican legislation. } \\
\text { Citizens have the right to } \\
\text { choose freely the language of } \\
\text { education and upbringing, } \\
\text { to learn the Karelian, Veps } \\
\text { and Finnish languages and } \\
\text { to receive general education } \\
\text { in these languages. The } \\
\text { republic ensures these rights } \\
\text { by creating the required } \\
\text { number of classes, groups. }\end{array}$ \\
\hline
\end{tabular}




\section{Konstantin Zamyatin}

cally amount to a lower level of institutionalization of the titular language. The difference is that the Karelian Law defines that the languages "can be used", whereas the language laws of the other republics define that the state languages of the republics "are used" and "have to be used". The problem is that the formulas like "are used" and "have to be used" are interpreted by implementers not as rules but almost as recommendations.

Therefore, one should bear in mind that even a relatively high level of institutionalization in some republics does not guarantee a similarly high level of implementation of the provisions (see Zamyatin 2014b for the study on policy implementation through governmental executive programs in the Finno-Ugric republics). Of the list of measures prescribed by the language laws, only few are actually implemented and the rest remains on paper. The language laws have neither direct enforcement, nor funding, because financial resources are assigned via separate administrative regulations. In this situation, much is left at the discretion of government officials. Further formulas opening the corridor for non-implementation and, thus, amounting to the deficiencies of laws in terms of their efficiency in pursuing the policy goals are: "can be used", "if possible", "if there is need for it", "according to the order defined in legislation" or "according to the legislation". The inclusion of these restrictive qualifications is more characteristic of the language laws in republics with weaker ethnic elites, but also e. g. of the Mari El language law after the 2001 amendment.

Legal provisions typically are not formulated as individual language rights. For example, there are only two citizens' rights in the Udmurtian language law - the restricted right to receive education in one's own language and the restricted right to make requests to the authorities in one's own language. In the Mari El language law, the second right is formulated more broadly as the right to communicate with authorities in one's own language, also at their sessions, as well as the right to receive oral information and documents in the state languages of the republic. Additionally, there is the individual right to choose personal names according to national traditions (article 51). Thus, the republican laws do not add anything new to the short list of rights provided by Russia's language law. The only extension of federal legislation was the establishment in the Mari El language law of the right to receive oral information and documents from authorities in the republican state languages. Implementation of rare language rights depends on the initiative of citizens, on their activeness in demanding their rights. However, a further deficiency is that even those 
few rights are not self-executing, that is, they cannot be invoked directly in court. A striking example is the right of parliamentarians and executive officials to speak in the language of their choice on authorities' sessions, which, however, is never used in practice. Furthermore, in court practice, the citizens' demands are typically refused.

Finally, one more deficiency is that language legislations in the republics under consideration do not create concrete mechanisms of responsibility for breaches of language legislation. The Komi language law is interesting, because it is noted there that individuals who create obstacles to citizens' ability to enjoy their choice of the state languages for communications bear responsibility according to defined order (article 6). The 2002 amendment broadened the possibility of the choice not just to the state languages, but to any language. The problem is that this responsibility is not further defined. Thus, the Komi provision is weaker than, for example, the provision of the infringement of the language legislation of the Kabardin-Balkarian Republic, where the Code "On Administrative Offences" contains concrete sanctions (Code KBR, 22 July 2003, Article 3.1; Vasil'eva 2007: 37-38).

\section{Conclusion}

The study shows that the expansion of titular languages became the policy goal in all the republics, but far from all domains were institutionalized for titular languages. It was only a certain range of regional authorities and a certain degree of institutionalization of titular languages, because the scope of their expansion was restricted both by the federal design and the parallel official status of Russian as the default setting effectively prevented this expansion by not requiring the use of the titular language (see Zamyatin 2014a: 103).

The data demonstrate that (1) the titular languages had not become the working languages of authorities, (2) but were partly institutionalized for the purpose of interaction with citizens, especially in providing visual and sometimes auditory information and (3) also partly but somewhat better institutionalized in the provision of public services. (4) The position of the titular languages as the language in office remains weak; (5) the languages are relatively better institutionalized in mass media and education. In institutionalized domains, mainly those elements of the official status that convey symbolic message of recognition were introduced in the case of 
titular languages. In its symbolic function, the official status works mostly as a symbol of national identity, and one might infer that exactly for that reason, the visual elements are central. However, symbolic use only indirectly promotes communicative use. The inclusion of restricting qualifications in relation to the institutionalized communicative elements might reveal the intention not to implement these conditioned provisions of the laws. As Alexandr Osipov (2012: 425) points out, the decouplement of the symbolic policies of recognition from instrumental policies is a characteristic of Russia's system of diversity management. This could also be a remnant of the Soviet-era practices of seeming recognition of the multinational character of the state along with the folklorization of cultures.

These results of the study on the situation of the languages in the public domains in Russia's national republics witness that this is a case of functional distribution of diglossia, when it is nearly impossible to expand the use in the public domains of a language with a lower status (Fishman 1967; the author is indebted to Tove Skutnabb-Kangas for this point, see Zamyatin 2015: 127). In a perceived "zero-sum" game, significant efforts might be needed in order to expand minority language use, which, however, could still fall short of the goals in conditions when the titular group and its ethnic elite are in the minority (see Zamyatin 2014a: 124-127). Therefore, the implication of the study is that a top-down approach through the expansion of official language use alone can hardly reverse language shift. Official status might be not of special help for revival, because it deals with auxiliary fields and does not influence language practices directly, although it might promote language prestige and, thus, indirectly change language attitudes and language practices. Further sociological and sociolinguistic research could concentrate on evaluating the impact of policy in order to test the link between official policy and language practices.

Konstantin Zamyatin Department of Finnish, Finno-Ugrian and Scandinavian Studies, P.O. Box 3, FI-00014 University of Helsinki, Finland $<$ konstazam@hotmail.com>

\section{Note}

1. Research for this article was made possible by a scholarship from the Finnish Cultural Foundation. 


\section{References}

BANNIKova 2001 = Татьяна Банникова: Кылъёс сярысь закон нош ик кутымтэ. «Удмурт Дунне», 26 октября.

Blommaert, JAN 1996: Language Planning as a Discourse on Language and Society: The Linguistic Ideology of a Scholarly Tradition. - Language Problems and Language Planning 20 (3): 199-222.

Cooper, Robert 1990: Language Planning and Social Change. New York: Cambridge University Press.

Cormack, Mike 2000: Minority Languages, Nationalism and Broadcasting: the British and Irish Examples. - Nations and Nationalism 6 (3): 383-398.

CYPANOV $2003=$ E. А. Цыпанов: Государственный ли коми язык с точки зрения его функционирования. - Проблемь и перспективы развития финно-угорских языков. Саранск: «Красный Октябрь». 31-4о.

Fishman, Joshua 1967: Bilingualism With and Without Diglossia; Diglossia With and Without Bilingualism. - Journal of Social Issues 23 (2): 29-38.

- 1991: Reversing Language Shift. Theoretical and Empirical Foundations of Assistance to Threatened Languages. Clevedon: Multilingual Matters.

Gorenburg, Dmitry P. 2003: Minority Ethnic Mobilization in the Russian Federation. New York: Cambridge University Press.

Gubaeva \& Malkov $1999=$ T. В. Губаева \& В. П. Малков: Государственный язык и его правовой статус. - Государство и право 7: 5-13.

GučIgov 2013 = Т.X. Гучигов: Статус государственных языков в республиках Северо-Кавказского федерального округа. - Вестник Воронежского государственного университета 2: 94-101.

Ishakova $2002=3$. А. Исхакова: Функциональное взаимодействие татарского и русского языков в современном Татарстане. - Язык и этнос на рубеже веков. Казань: Магариф, 9-25.

Ivanova 2010 = Ирма Иванова: Борьба за самоидентификацию // Интернет-газеmа «Каспаров.Ру», 29 июня.

$<$ http://www.kasparov.ru/material.php?id= $4 \mathrm{C}_{29}$ ECC7088C2 $>$ Access to this resource in Russia was restricted according to the legislation.

KATUNIN 2009 = Дмитрий Катунин: Языковое законодательство в республиках Сибири. - Язык и культура. 4 (8): 3-24.

Kymlicka, Will 2001: Politics in the Vernacular: Nationalism, Multiculturalism and Citizenship. Oxford: Oxford University Press.

Osipov, Alexander 2012: Implementation Unwanted? Symbolic vs. Instrumental Policies in the Russian Management of Ethnic Diversity. - Perspectives on European Politics \& Society 13 (4): 425-442.

PAtrick, Donna 2010: Language Dominance and Minorization. - J. Jaspers, J. Östman \& J. Verschueren (eds): Society and Language Use. Amsterdam: John Benjamins. 176-191.

Ruíz Vieytez, Eduardo J. 2004: Official Languages and Minority Languages: Issues about Their Legal Status through Comparative Law. - II Mercator International Symposium: Europe 2004: A new framework for all languages? <http://www.ciemen.org/mercator/pdf/simp-vieytez-ang.pdf> 


\section{Konstantin Zamyatin}

SEmёNOv 2008 = Ю. В. Семенов: О языковой политике. - Этноконфессиональная ситуация в Приволжском федеральном округе. Бюллетень Сети этнологического мониторинга и раннего предупреждения конбликтов, № 135.

Sokolov, Aleksandr 2002: The Situation of Ethnic Minorities. - On the Human Rights Situation in the Russian Federation. Collection of Reports. Moscow: Moscow Helsinki Group.

TaAgePera, Rein 1999: The Finno-Ugric Republics and the Russian State. London: Hurst and Co.

Ulasiuk, Iryna 2011: Legal Protection of Linguistic Diversity in Russia: Past and Present. - Journal of Multilingual \& Multicultural Development 32 (1): 71-83.

VASIL'Eva $2008=$ Л. Н. Васильева: Двуязычие нормативных актов в Российской Федерации: совершенствование правовой основы. - Журнал российского права 8: 24-31.

- $2007=$ Л. Н. Васильева: Комментарий к Закону Российской Федерации “О языках народов Российской Федерации” (постатейный). Москва: Юстицинформ.

Zamyatin, Konstantin 2012a: The Education Reform in Russia and its Impact on Teaching of the Minority Languages: an Effect of Nation-Building? - Journal on Ethnopolitics and Minority Issues in Europe 11 (1): 17-47.

- 2012b: From Language Revival to Language Removal? The Teaching of Titular Languages in the National Republics of Post-Soviet Russia. - Journal on Ethnopolitics and Minority Issues in Europe 11 (2): 75-102.

- 2012c: The Finno-Ugric Languages in Russian Education: Changing Legal-Institutional Framework and Falling Access to Native Language Study. - Études finnoougriennes 44: 197-272.

- 2013a: Sovereignisation and State Languages: Early Formation of Language Policy of Russia’s Finno-Ugric Republics under the Conditions of the USSR Disintegration. Finnisch-Ugrische Mitteilungen 36: 123-165.

- 2013b: Finno-Ugric Republics and Their State Languages: Balancing Powers in Constitutional Order. - Journal de la Société Finno-Ougrienne 94: 337-381.

- 2013c: Official Status As a Tool of Language Revival? A Study of the Languages Laws in Russia's Finno-Ugric Republics. - Journal of Ethnology and Folkloristics 7 (1): 125153.

- 2014a: An Official Status for Minority Languages? A Study of State Languages in Russia's Finno-Ugric Republics. Uralica Helsingiensia 6. Helsinki: Finno-Ugrian Society.

- 2014b: 'Maintaining and Developing the Languages': Participation in DecisionMaking and Support for Language Revival in Russia's Finno-Ugric Republics. Finnisch-Ugrische Mitteilungen 38: 193-253.

- 2015: The Evolution in Language Ideology of Post-Soviet Russia. The Fate of the State Languages of the Republics. - Heiko Marten, Michael Rießler, Janne Saarikivi \& Reetta Toivanen (eds): Cultural and Linguistic Minorities in the Russian Federation and the European Union. Comparative Studies on Equality and Diversity Series: Multilingual Education, Vol. 13. Berlin: Springer. 279-313. In print. 


\section{Legal acts (in chronological order by region)}

\section{Russian Federation}

RSFSR Law, 25 October 1991 (amended by the Federal Laws, 24 July 1998 and 11 December 2002) = Закон РСФСР от 25.10.1991 г. № 1807-I “О языках народов РСФСР” (также в редакции Федерального Закона от 24.07.1998 г. № 126 и с изменениями и дополнениями, внесенными Федеральным Законом от 11.12.20о2 г. № 165).

RF Law, 7 February 1992 = Закон Российской Федерации от 7 февраля 1992 г. № 2300-I “О защите прав потребителя".

Fundamentals of the Legislation on Notariate, 11 February $1993=$ Основы Законодательства Российской Федерации “О нотариате” от 11 февраля 1993 г. № 4462-I.

Constitution of the Russian Federation, 12 December $1993=$ Конституция Российской Федерации, принята на всенародном голосовании 12 декабря 1993 г.

Federal Law, 31 July 1995 = Федеральный Закон от 31.07.1995 г. № 119 "Об основах государственной службы Российской Федерации".

RF Government Decree, 8 July 1997 = Постановление Правительства Российской Федерации от 8.07.1997 г. № 828 “Об утверждении Положения о паспорте гражданина Российской Федерации, образца бланка и описания паспорта гражданина Российской Федерации".

Federal Law, 15 November 1997 = Федеральный Закон от 15.11.1997 г. № 143 “Об актах гражданского состояния".

RF Constitutional Court Judgment, 27 April 1998 = Постановление Конституционного Суда Российской Федерации от 27.04.1998 г. № 12-П “По делу о проверке конституционности отдельных положений части первой статьи 92 Конституции Республики Башкортостан, части первой статьи 3 Закона Республики Башкортостан «О Президенте Республики Башкортостан» (в редакции от 28 августа 1997 года) и статей 1 и 7 Закона Республики Башкортостан «О выборах Президента Республики Башкортостан" (вместе с особым мнением судьи Конституционного Суда РФ В. Г. Стрекозова).

Federal Law, 6 October 1999 = Федеральный Закон от 6.10.1999 г. № 184 "Об общих принципах организации законодательных (представительных) и исполнительных органов государственной власти субъектов Российской Федерации”.

Federal Law, 25 June 2002 = Федеральный Закон от 25.06.2002 г. № 73 "Об объектах культурного наследия (памятниках истории и культуры) народов Российской Федерации".

Federal Law, 27 May 2003 = Федеральный Закон от 27.05.2003 г. № 58 “О системе государственной службы Российской Федерации".

Federal Law, 27 July 2004 = Федеральный Закон от 27.07.2004 г. № 79 “О государственной гражданской службе Российской Федерации".

Federal Law, 1 June 2005 = Федеральный Закон от 1.06.2005 г. № 53 “О государственном языке Российской Федерации".

Federal Law, 27 July 2006 = Федеральный Закон от 27.07.2006 г. № 149 "Об информации, информационных технологиях и о защите информации”. 


\section{Konstantin Zamyatin}

Federal Law, 2 March 2007 = Федеральный Закон от 2.03.2007 г. № 25 “О муниципальной службе в Российской Федерации".

Federal Law, 9 February 2009 = Федеральный Закон от 9.02.2009 г. № 8 “Об обеспечении доступа к информации о деятельности государственных органов и органов местного самоуправления".

Federal Law, 29 December 2012 = Федеральный Закон от 29.12.2012 г. № 273 “Об образовании в Российской Федерации".

\section{Komi Republic}

KR Law, 28 May 1992 (amended by the KR Laws, 16 July 2002 and 6 July 2009) = Закон Республики Коми от 28.05.1992 г. № 58 “О государственных языках Республики Коми” (с изменениями и дополнениями, внесенными Законами Республики Коми от 16.07.2002 № 76 и 6.07.2009 № 63).

KR Council of Ministers, 25 April 1994 = Постановление Совета Министров Республики Коми от 25.04.1994 г. № 167 “О Республиканской термино-орфографической комиссии при Совете Министров Республике Коми”.

KR Law, 24 October 1994 (new Law, 19 December 2006) = Закон Республики Коми от 24.10.1994 г. № 2 “О статусе депутата Государственного Совета Республики Коми” (новый Закон от 19.12.2006 № 140).

Rules of the Procedure, 7 February 1995 (new Rules of the Procedure, 18 December 2002) = Регламент Государственного Совета Республики Коми, утвержден Постановлением Государственного Совета Республики Коми от 7.02.1995 г. (новый Регламент от 18.12.2002).

KR Law, 15 June 1995 = Закон Республики Коми от 15.06.1995 г. № 14 “О выборах в органы государственной власти в Республике Коми".

KR Law, 25 March 1996 = Закон Республики Коми от 25.03.1996 г. № 12 “О государственной службе Республики Коми".

KR Ministry for Nationalities Affairs Order, 15 August 1997 (new Order 13 May 2004) = Приказ Министерства по делам национальностей Республики Коми от 15.08.1997 № 119 (новый Приказ от 13.05.2004).

KR Election, 16 June 1998 = Кодекс Республики Коми о выборах и референдумах в Республике Коми от 16.06.1998 г. № 26.

KR Government Decree, 23 Мау 2002 = Постановление Правительства Республики Коми от 23.05.2002 г. № 63 “Об утверждении Регламента Правительства Республики Коми".

KR Law, 16 October 2002 = Закон Республики Коми от 16.10.2002 г. № 101 “О порядке опубликования и вступления в силу законов Республики Коми”.

KR Government Decree, 18 October 2004 = Постановление Правительства Республики Коми от 18.10.2004 г. № 178 “О Правилах написания географических названий на коми языке".

KR Law, 21 May 2004 = Закон Республики Коми от 21.05.2004 г. № 30 “О некоторых вопросах в области сохранения, использования, популяризации и государственной охраны объектов культурного наследия (памятников истории и культуры) на территории Республики Коми”. 
KR Law, 5 March 2005 = Закон Республики Коми от 5.03.2005 г. № 10 “О некоторых вопросах государственной гражданской службы Республики Коми”.

KR Law, 7 July 2006 = Закон Республики Коми от 7.07.2006 г. № 65 "О выборах, peферендумах и опросе в Республике Коми".

KR Law, 21 December 2007 = Закон Республики Коми от 21.12.2007 г. № 133 “О некоторых вопросах муниципальной службы в Республике Коми".

KR Government Decree, 5 February 2008 = Постановление Правительства Республики Коми от 5.02.2008 г. № 20.

KR Government Decree, 24 February 2009 = Постановление Правительства Республики Коми от 24.02.2009 г. № 35 .

\section{Republic of Mari El}

RME Law, 10 November 1993 (new Law, 11 June 2003) = Закон Республики Марий Эл от 10.11.1993 г. “О выборах депутатов Государственного Собрания Республики Марий Эл” (новый Закон от 11.06.2003).

RME Law, 15 February 1994 = Закон Республики Марий Эл от 15.02.1994 г. № 43 "О статусе депутата Государственного Собрания Республики Марий Эл".

RME Law, 23 February 1995 = Закон Республики Марий Эл от 23.02.1995 г. № 194 “О государственной службе в Республике Марий Эл".

RME Law, 26 October 1995 (amended by the Laws of the Republic of Mari El, 19 September 2001, 2 December 2008, 16 March 2009, 10 March 2011) = Закон Peспублики Марий Эл от 26.10.1995 г. № 290 “О языках в Республике Марий Эл” (в редакции Закона от 19.09.2001 г. № 33 и с изменениями и дополнениями, внесенными Законами от 2.12.2008 № 68, 16.03.2009 № 13, 10.03.2011 № 9).

RME Law, 7 April 1998 = Закон Республики Марий Эл от 7.04.1998 г. № 73 “О муниципальной службе в Республике Марий Эл".

RME Government Decree, 8 July 2000 = Постановление Правительства Республики Марий Эл от 8.07.2000 г.

RME Government Decree, 29 March 2001 = Постановление Правительства Республики Марий Эл от 29.03.2001 г.

RME Government Decree, 10 April 2001 (new Rules of the Procedure, 2 October 2006) $=$ Постановление Правительства Республики Марий Эл от 10.04.2001 г. № 120 “О Регламенте Правительства Республики Марий Эл" (новое Постановление от 2.10.2006 № 204).

RME Law, 18 September 2001 = Закон Республики Марий Эл от 18.09.2001 г. № 23 "О Правительстве Республики Марий Эл".

RME Law, 7 December 2001 = Закон Республики Марий Эл от 7.12.2001 г. № 45 “О Государственном Собрании Республики Марий Эл".

RME Law, 11 June 2003 = Закон Республики Марий Эл от 11.06.2003 г. № 21 "О peферендуме Республики Марий Эл".

Yoshkar-Ola Court Judgment, 23 March 2004 = Постановление суда города ЙошкарОла от 23.03.2004. 


\section{Konstantin Zamyatin}

RME Ministry, 12 November 2004 = Письмо Министерства внутренних дел Республики Марий Эл от 12.11.2004 г.

RME Law, 28 June 2005 = Закон Республики Марий Эл от 28.06.2005 г. № 133 “О постоянных комитетах Государственного Собрания Республики Марий Эл”.

RME FMS Department Communication, 10 October $2007=$ Письмо Департамента Федеральной миграционной службы по Республике Марий Эл от 10.10.2007 г.

RME Government Communication, 16 November 2007 = Письмо Правительства Pеспублики Марий Эл от 16.11.2007 г.

RME Government Decree, 14 December 2008 = Постановление Правительства Pеспублики Марий Эл от 14.12.2008 г.

Rules of the Procedure of the State Assembly of the Republic of Mari El, 24 September 2009 = Регламент Государственного Собрания Республики Марий Эл, утвержден Постановлением Государственного Собрания Республики Марий Эл от 24.09.2009 г. № 770 .

\section{Udmurt Republic}

UR Law, 23 January 1994 (new Laws, 1 June 2003 and 13 April 2007) = Закон Удмуртской Республики от 23.01.1994 г. “О выборах депутатов Государственного Совета Удмуртской Республики” (новый Законы от 1.06.2003 № 27 и 13.04.2007 г. № 803).

UR Law, 14 December 1994 (new Laws, 20 February 2001 and 5 December 2007) = 3aкон Удмуртской Республики от 14.12.1994 г. № 669 “О Государственном Совете Удмуртской Республики” (новые Законы от 6.03.2001 № 7 и 5.12.2007 № 65).

UR State Council Rules of the Procedure, 26 April 1995 (new Rules of the Procedure, 17 April 2001, 25 November 2008) = Постановление Правительства Республики от 26.04.1995 г. № 120 “О Регламенте Правительства Удмуртской Республики" (новые Постановления от 17.04.2001 г. № 390 и 25 ноября 2008 г. № 183).

UR Law, 16 May 1995 (new Law, 2 March 2001) = Закон Удмуртской Республики от 16.05.1995 г. № 30 “О Правительстве Удмуртской Республики” (новый Закон от 2.03.2001 № 6).

UR Law, 30 May 1995 = Закон Удмуртской Республики от 30.05.1995 г. № 50 “О постоянных комиссиях Государственного Совета Удмуртской Республики”.

UR Government Decree, 13 November 1995 = Постановление Правительства Удмуртской Республики от 13.11.1995 г. № 316 “О республиканской термино-орфографической комиссии по удмуртскому языку”.

UR Law, 26 November 1997 = Закон Удмуртской Республики от 26.11.1997 г. № 523 “О государственной службе Удмуртской Республики".

UR Law, 25 February 1999 (new Law, 20 March 2008) = Закон Удмуртской Республики от 25.02.1999 г. № 746 “О муниципальной службе в Удмуртской Республике” (новый Закон от 20.03.2008 № 10).

UR Law, 27 November 2001 (amended by the UR Law, 21 June 2010) = Закон Удмуртской Республики от 27.11.2001 г. № 6о “О государственных языках Удмуртской Республики и иных языках народов Удмуртской Республики (с изменениями и дополнениями, внесенными Законом Удмуртской Республики от 21.06.2010 № 26). 
UR Law, 18 December 2002 (new Law, 29 March 2007) = Закон Удмуртской Республики от 18.12.2002 г. № 73 “О референдуме Удмуртской Республики” (новый Закон от 29.03.2007 № 10).

UR Government Decree, 24 January 2003 = Постановление Правительства Удмуртской Республики от 24.01.2003 г. № 100 “О регламенте Правительства Удмуртской Республики".

UR Law, 5 July 2005 = Закон Удмуртской Республики от 5.07.2005 г. № 38 “О государственной гражданской службе Удмуртской Республики".

UR Government Decree, 7 November 2005 = Постановление Правительства Удмуртской Республики от 7.11.2005 г. № 159 “Об утверждении порядка оформления наименований географических объектов и установки дорожных обозначений и указателей на государственных языках Удмуртской Республики".

UR Government Decree, 5 December 2005 = Постановление Правительства Удмуртской Республики от 5.12.2005 г. № 1164 “О признании утратившим силу постановления Правительства Удмуртской Республики от 13 ноября 1995 года № 316 «О республиканской термино-орфографической комиссии по удмуртскому языку»".

UR President Decree, 8 December 2005 = Указ Президента Удмуртской Республики от 8.12.2005 г. № 148 “О Республиканской термино-орфографической комиссии по удмуртскому языку”.

UR Law, 26 February 2008 = Закон Удмуртской Республики от 26.02.2008 г. № 1 “О статусе депутата Государственного Совета Удмуртской Республики".

\section{Republic of Mordovia}

RM Law, 17 February 1994 (new Law 27 June 2006) = Закон Республики Мордовия от 17.02.1994 г. № “О выборах депутатов Государственного Собрания Республики Мордовия” (новый Закон от 27.06.2006 г. № 41).

RM State Assembly Rules of the Procedure, 10 March 1995 (new Rules of the Procedure, 14 February 2002) = Регламент Государственного Собрания Республики Мордовия, утвержден Законом Республики Мордовия от 10.03.1995 г. № 61 (новый Регламент от 14.02.2002 № 602).

RM Law, 10 March 1995 = Закон Республики Мордовия от 10.03.1995 г. № 62 "О комитетах и комиссиях Государственного Собрания Республики Мордовия”.

RM Law, 27 July 1995 (new Law, 23 January 2004) = Закон Республики Мордовия от 27.07.1995 г. № 267 “О референдуме Республики Мордовия” (новый Закон от 23.01.2004 № 19).

RM Law, 26 January 1996 = Закон Республики Мордовия от 26.01.1996 г. № 10 “О государственной службе Республики Мордовия".

RM Law, 16 April 1996 (new Law, 12 November 2001) = Закон Республики Мордовия от 16.04.1996 г. “О Правительстве Республики Мордовия” (новый Закон От 12.11.2001 № 42).

RM Law of the Republic of Mordovia "On the Status of the Deputy of the State Assembly of the Republic of Mordovia”, 28 February 1997 = Закон Республики Мордовия от 20.02.1997 г. № 17 “О статусе депутата Государственного Собрания Республики Мордовия". 


\section{Konstantin Zamyatin}

RM Law, 26 May 1998 (amended by the Law of the Republic of Mordovia, 12 March 2010) = Закон Республики Мордовия от 26.05.1998 г. № 19 “О государственных языках в Республике Мордовия” (с изменениями и дополнениями, внесенными Законом Республики Мордовия от 12.03.2010 № 4).

RM Government Decree, 10 June 1998 = Постановление Правительства Республики Мордовия от 10.06.1998 г. № 226 “О Регламенте Правительства Республики Мордовия".

RM Law, 28 May 1999 = Закон Республики Мордовия от 28.05.1999 г. № 30 “О муниципальной службе в Республике Мордовия".

RM Law, 1 June 2000 = Закон Республики Мордовия от 1.o6.20о0 г. “О правовых актах муниципальных органов и муниципальных служащих Республики Мордовия".

RM Law, 21 February 2002 = Закон Республики Мордовия от 21.02.2002 г. № 10 “О правовых актах Республики Мордовия".

RM Law, 19 March 2004 = Закон Республики Мордовия от 19.03.2004 г. № 34 “О Государственном Собрании Республики Мордовия".

RM Government Decree, 25 October 2010 = Постановление Правительства Республики Мордовия от 25.10.2010 г. № 405 “О Республиканской термино-орфографической комиссии по мордовскому (мокшанскому и эрзянскому) языку”.

\section{Republic of Karelia}

KASSR Law, 6 May 1990 = Закон Карельской ACCP от 6.05.1990 г. "О порядке опубликования и вступления в силу Законов Карельской АССР и других нормативно-правовых актов Верховного Совета Карельской АССР”.

RK Law, 19 April 1991 = Закон Республики Карелия от 19.04.1991 г. “О статусе народного депутата Верховного Совета Республики Карелия".

KASSR Law, 24 April 1991 = Закон Карельской ACCP от 24.04.1991 г. "О референдуме в Карельской АССР".

RK State Committee Communication, 17 February 1993 = Письмо Государственного комитета Республики Карелия по труду и социальным вопросам от 17.03.1993 г.

RK Law, 10 November 1993 (new Law 28 November 1997) 1991 = Закон Республики Карелия от 10.11.1993 г. “О референдуме в Республике Карелия” (новый Закон от 28.11.1997).

RK Law, 17 January 1994 = Закон Республики Карелия от 17.01.1994 г. № XII-23/611 “О выборах депутатов Законодательного Собрания Республики Карелия”.

RK Legislative Assembly Rules of the Procedure, 17 May 1994 (new Rules of the Procedure, 22 February 2007) = Регламент Законодательного Собрания Республики Карелия, утвержден Постановлением Правительства Республики Карелия от 17.05.1994 г. (новый Регламент от 28.11.1997).

RK Legislative Assembly Decree, 17 May 1994 = Постановление Законодательного Собрания Республики Карелия от 17.05.1994 г. № 1 “О вступлении в права Законодательного Собрания Республики Карелия”.

RK Law, 14 September 1994 = Закон Республики Карелия от 14.09.1994 г. № 6 “О комитете Законодательного Собрания Республики Карелия”. 
RK Law, 24 January 1995 = Закон Республики Карелия от 24.01.1995 г. № 31 “О культуре".

RK Law, 5 December 1996 = Закон Республики Карелия от 5.12.1996 г. № 160 “О муниципальной службе в Республике Карелия".

RK Law, 10 January 1997 = Закон Республики Карелия от 10.01.1997 г. № 167 “О государственной службе Республики Карелия".

RK Government Chairman Decree, 25 Мау 1998 = Постановление Председателя Правительства Республики Карелия от 25.05.1998 г. № 340 “О термино-орфографической комиссии".

RK Law, 27 April 1999 = Закон Республики Карелия от 27.04.1999 г. № 348 “О Правительстве Республики Карелия".

RK Law, 24 May 2000 = Закон Республики Карелия от 24.05.2000 г. № 410 “О нормативно-правовых актах Республики Карелия".

RK Head Decree, 29 May 2003 = Указ Главы Республики Карелия от 29.05.2003 г. № 94 “О термино-орфографической комиссии при Главе Республики Карелия”.

RK Law, 19 March 2004 = Закон Республики Карелия от 19.03.2004 г. № 759 “О государственной поддержке карельского, вепсского и финского языков в Республике Карелия".

RK Legislative Assembly Decree, 24 May 2007 = Постановление Законодательного Собрания Республики Карелия от 24.05.2007 г. № 439 “О комитете Законодательного Собрания Республики Карелия".

\section{Republic of Tatarstan}

RT Law, 12 January 2013 = Закон Республики Татарстан от 12.01.2013 г. № 1 “О6 и с пользовании татарского языка как государственного языка Республики Татарстан".

\section{Kabardin-Balkarian Republic}

KBR Code, 22 July 2003 = Кодекс Кабардино-Балкарской Республики от 22.07.2003 г. № 66 “Об административных нарушениях". 